\title{
Vibratory Finishing as a Decontamination Process
}

October 1980

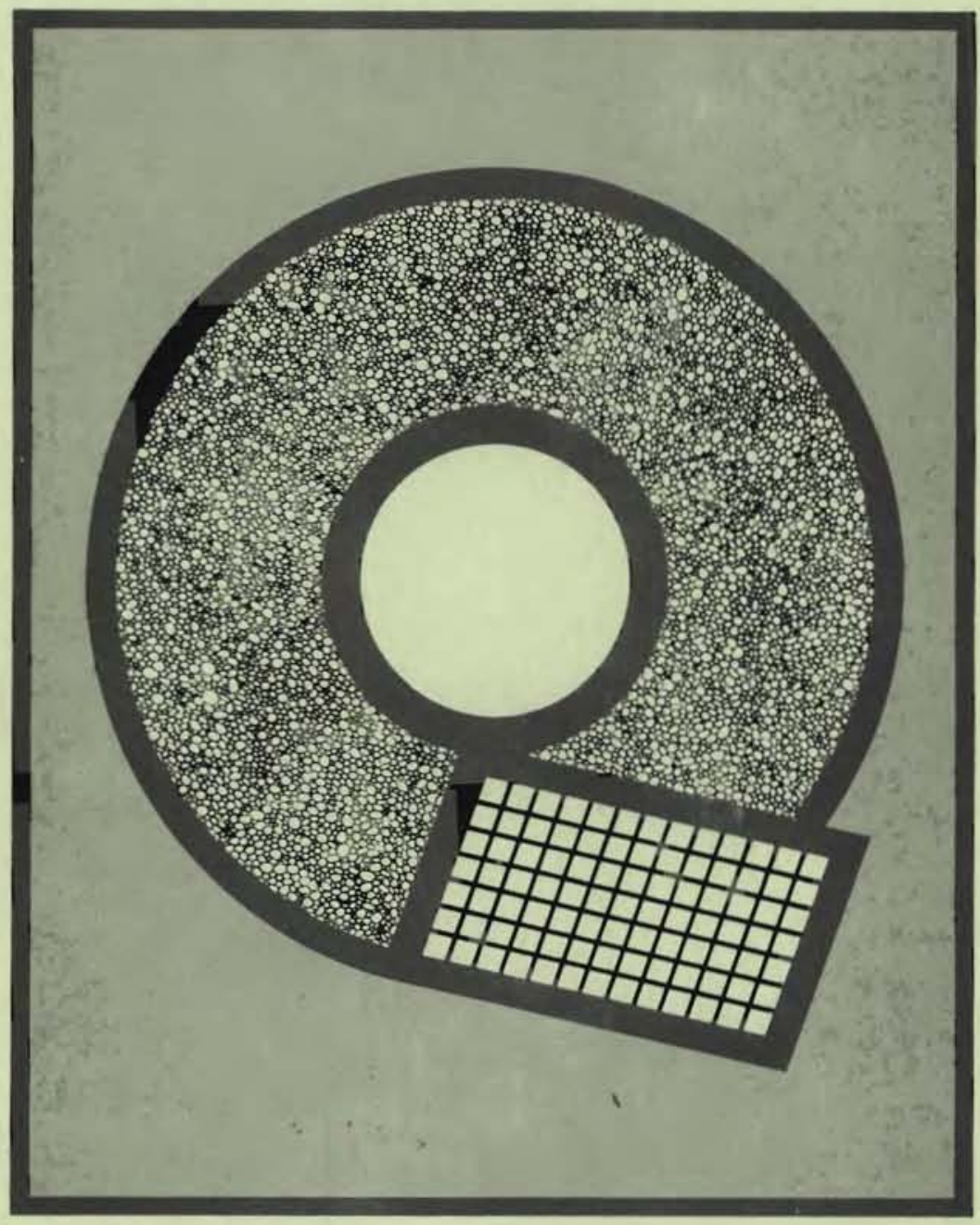

Prepared for the U.S. Department of Energy under Contract DE-ACO6-76RLO 1830

Pacific Northwest Laboratory

Operated for the U.S. Department of Energy

by Battelle Memorial Institute 
NOTICE

This report was prepared as an account of work sponsored by the United States Government. Neither the United States nor the Department of Energy, nor any of their employees, nor any of their contractors, subcontractors, or their employees, makes any warranty, express or implied, or assumes any legal liability or responsibility for the accuracy, completeness or usefulness of any information, apparatus, product or process disclosed, or represents that its use would not infringe privately owned rights.

The views, opinions and conclusions contained in this report are those of the contractor and do not necessarily represent those of the United States Government or the United States Department of Energy.

\author{
PACIFIC NORTHWEST LABORATORY \\ operated by \\ BATTELLE \\ for the \\ UNITED STATES DEPARTMENT OF ENERCY \\ Under Contract DE-AC06-76RLO 1830
}

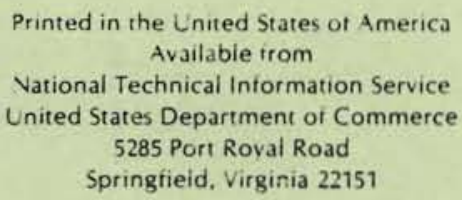

Price: Printed Copy 5

$\because$ Microfiche $\$ 3.00$

$\begin{array}{cc}* \text { Pages } & \text { Selling Price } \\ & \\ 001-025 & \$ 4.00 \\ 026-050 & \$ 4.50 \\ 051-075 & \$ 5.25 \\ 076-100 & \$ 6.00 \\ 101-125 & \$ 6.50 \\ 126-150 & \$ 7.25 \\ 151-175 & \$ 8.00 \\ 176-200 & \$ 9.00 \\ 201-225 & \$ 9.25 \\ 226-250 & \$ 9.50 \\ 251-275 & \$ 10.75 \\ 276-300 & \$ 11.00\end{array}$


PNL -3336

UC -70

\section{9}

\section{VIBRATORY FINISHING AS A DECONTAMINATION PROCESS}

M. W. McCoy

H. W. Arrowsmith

R. P. Allen

October 1980

Prepared for the U.S. Department of Energy under Contract DE-ACO6-76RLO 1830

Pacific Northwest Laboratory

Richland, Washington 99352 

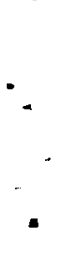


\section{SUMMARY}

Research conducted at the Pacific Northwest Laboratory for the United States' Department of Energy showed that vibratory finishing is a rapid and effective technique for removing plutonium and other radionuclide contamination from a variety of metallic and nonmetallic surfaces. The major objective of this research is to develop vibratory finishing into a large-scale decontamination technique that can economically remove transuranic and other surface contamination from large volumes of waste produced by the operation and decommissioning of retired nuclear facilities. The successful development and widespread application of this decontamination technique would substantially reduce the volume of waste requiring expensive geologic disposal. 0ther benefits include exposure reduction for decontamination personnel and reduced risk of environmental contamination.

Laboratory-scale studies conducted by Pacific Northwest Laboratory, in cooperation with Rockwell Hanford Operations Company and UNC Nuclear Industries, showed that vibratory finishing can rapidly reduce the contamination level of transuranic-contaminated stainless steel and Plexiglas ${ }^{\circledR}$ to well below the $10-n C i / g$ limit. For example, the plutonium contamination levels of steel tools and stainless steel glove-box panels and ventilation ducts have been reduced from greater than $4 \times 10^{5} \mathrm{dis} / \mathrm{min} \cdot 100 \mathrm{~cm}^{2}$ to less than $10,000 \mathrm{dis} / \mathrm{min} \cdot 100 \mathrm{~cm}^{2}$ in one hour of processing time. Other objects that were decontaminated by vibratory finishing include Plexiglas ${ }^{\circledR}$ panels, glass tanks, Neoprene ${ }^{\circledR}$ gaskets, rubber gaskets, Hypalon ${ }^{\circledR}$ gloves, polyvinyl chloride sheet plastic and vinyl bag-out bags.

In addition to the laboratory studies, the capability of vibratory finishing as a decontamination process was demonstrated on a large scale. The first decontamination demonstration was conducted at the Hanford $\mathrm{N}$-Reactor, where a vibratory finisher was installed to reduce personnel exposure during the sumer outage. Items decontaminated included fuel spacers, process-tube end caps, process-tube inserts, pump parts, ball-channel inspection tools and miscellaneous hand tools. A second demonstration is currently being conducted in the decontamination facility at the Hanford 231-z Building. During this demonstration, transuraniccontaminated material from decommissioned plutonium facilities is being decontaminated to less than $10 \mathrm{nCi} / \mathrm{g}$ to minimize the volume of material that will require geologic disposal. Items that are being decontaminated include entire glove boxes, process-hood structural material and panels, process tanks, process-tank shields, pumps, valves and hand tools used during the decormissioning work.

\footnotetext{
(QTradename of Rohm and Haas Co. @Tradename of E. I. duPont deNemours Co. (Hypalon and Neoprene).
} 
Solution handling systems were also developed to minimize the generation of secondary waste. In addition, waste-treatment processes were developed to further minimize the volume of waste generated by vibratory finishing and to convert this waste into an approved form for disposal.

Vibratory finishing has great potential for both exposure-reduction and volume-reduction applications. The simplicity and versatility of vibratory finishing combined with minimal operator requirements make vibratory finishing particularly suitable for field decontamination installations. 
SUMMARY

INTRODUCTION

VIBRATORY-FINISHING PROCESS

TYPES OF VIBRATORY FINISHERS

OPERATING THE VIBRATORY FINISHER

MEDIA

MEDIA SELECTION

COMPOUND

VIBRATORY-FINISHING DECONTAMINATION STUDIES

INITIAL TESTS .

N-REACTOR DEMONSTRATION

USE OF STEEL MEDIA

TRANSURANIC DECONTAMINATION TESTS

TRANSURANIC DECONTAMINATION DEMONSTRATION

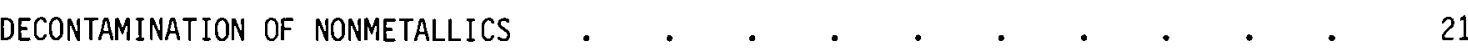

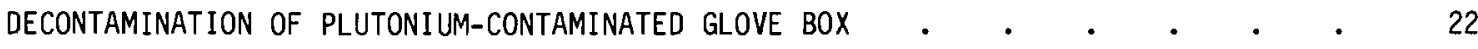

ADDITIONAL VIBRATORY-FINISHING TESTS AND CONSIDERATIONS $\quad$ - $\quad$ • $\quad$ • $\quad$ • $\quad$ • 25

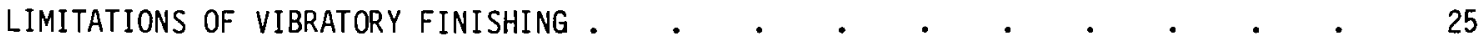

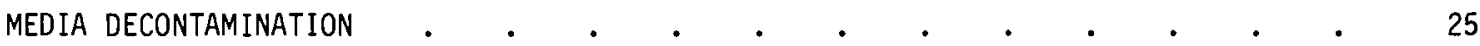

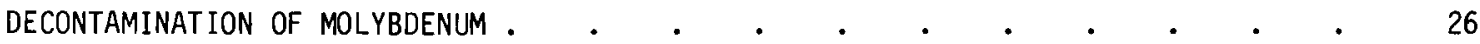

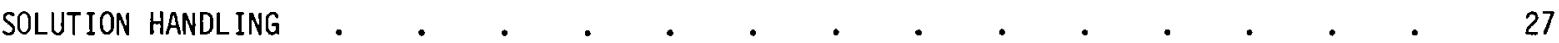

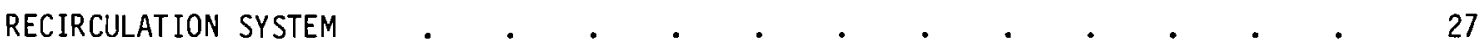

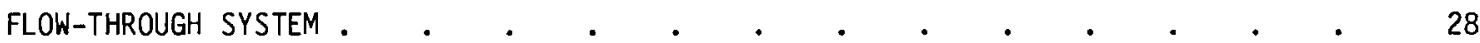

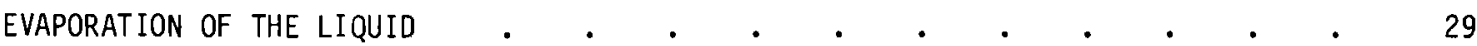

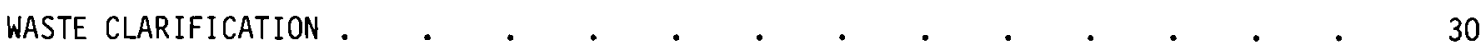

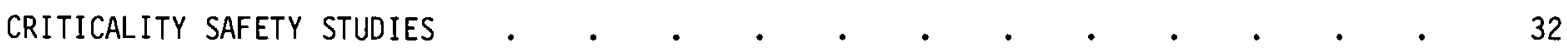

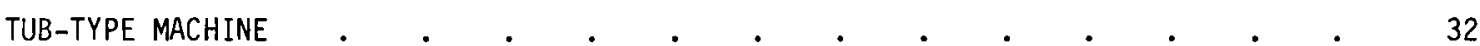

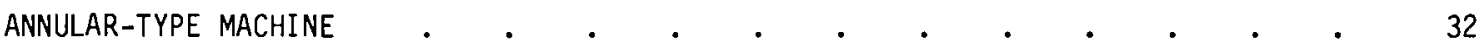

TECHNOLOGY TRANSFER •

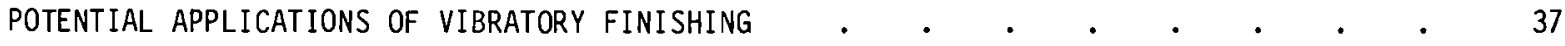

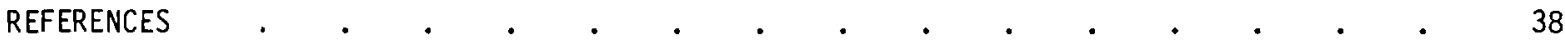


1 Schematic Drawing of the Vibratory-Finishing System Used for Decontamination and Pretreatment Studies

2 Typical Sections of Pipe Before and After Vibratory Finishing

3 Outboard Motor Parts Deburred Using Vibratory Finishing

4 Process-Tube End Caps Demonstrate the Ability of Vibratory Finishing to Successfully Clean Threads

6 Stainless Steel, Plexiglas and Neoprene Decontaminated by Vibratory Finishing

7 Standard Batch Tub-Type Vibratory Finisher with a 4-ft ${ }^{3}$ Capacity • • • . 6

8 Large Batch Tub-Type Vibratory Finisher Used to Deburr Diesel Engine Blocks $\quad$ • 6

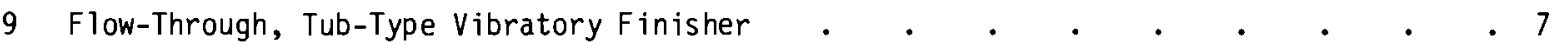

10 Twelve-Cubic-Foot Annular Vibratory Finisher Equipped with a Separator Screen $\quad$ • 7

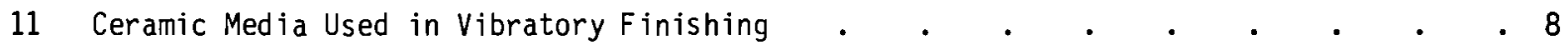

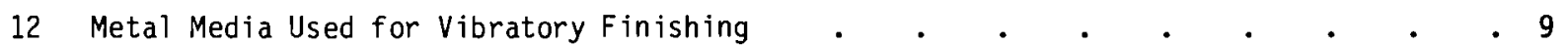

\begin{tabular}{l} 
Pipe Clamps from the Hanford N-Reactor Being Decontaminated in a \\
Vibratory Finisher \\
\hline
\end{tabular}

14 Carbon Steel Rings from the Hanford N-Reactor Decontaminated by $\quad$. . . . . 12

15 Process-Tube End Caps and Inserts Before (Left) and After (Right)

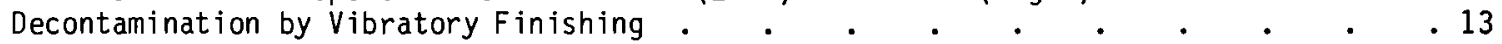

16 Electric Pump Motor Housing from a Hanford N-Reactor Valve Decontaminated

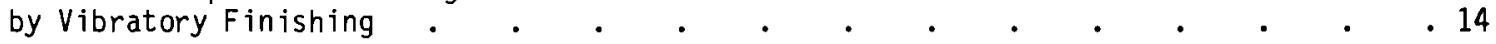

17 Hand Tools from Hanford N-Reactor Decontaminated by Vibratory Finishing • • . 14

18 Ball-Channel Inspection Tools Used at Hanford N-Reactor After Decontamination by Vibratory Finishing . . . . . . . . . . . . . . . 15

19 Four-Cubic-Foot, Tub-Type Vibratory-Finishing System With Recirculating Compound

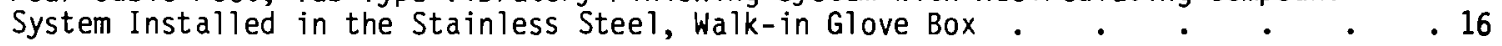

20 Fuel Spacers from Hanford $\mathrm{N}$-Reactor Before (Top) and After (Bottom) Decontamination

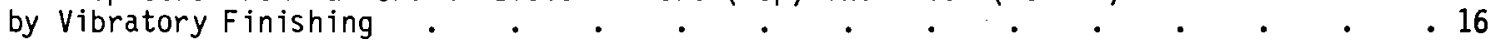

21 Contamination Level Versus Time for Plutonium-Contaminated Glove-Box Pieces Vibratory-Finished for 60 min in Steel Media Followed by $60 \mathrm{~min}$ in Ceramic Media

22 Plutonium-Contaminated Nonmetallic Material Decontaminated by Vibratory Finishing .

23 Plutonium-Contaminated Glass Decontaminated by Vibratory Finishing

24 Plutonium-Contaminated Glove Box Being Disassembled Prior to Decontamination by Vibratory Finishing 
27 Recirculation System for Liquid Compound Used in Vibratory-Finishing

Decontamination

28 Flow-Through System for Liquid Compound Used in Vibratory-Finishing Decontamination

29 Dual-Phase Vacuum Evaporator Used to Heat Liquid Waste From

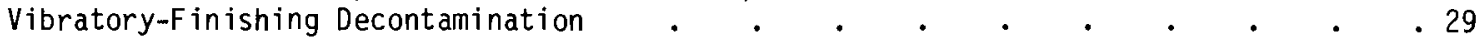

$30 \quad$ Clarification of Vibratory-Finishing Waste Using Polyelectrolytes .

31 Keff Versus Material Height for a 12- $\mathrm{ft}^{3}$ Annular Vibratory Finisher

32 Keff Versus Material Height for a 12-ft ${ }^{3}$ Annular Vibratory Finisher with 1-in. Water Equivalent Reflection . . . . . . . . . . . . 33

33 Keff Versus Material Height for a 12-ft $\mathrm{f}^{3}$ Annular Vibratory Finisher

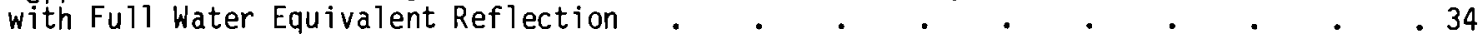

34 Critical Mass Versus Plutonium Concentration for a 12- $\mathrm{ft}^{3}$ Annular Finisher for Bare, 1-in. Water Equivalent and Full Water Reflection . . . . . . . 35

\section{TABLES}

1 Characteristics of Slow- and Fast-Cutting Media $\quad . \quad$. $\quad . \quad$. $\quad . \quad$. $\quad . \quad 9$

2 Decontamination of Beta/Gamma-Contaminated Components Using Vibratory Finisher with Steel Media

3 Decontamination of Plutonium-Contaminated Glove-Box Sections Using Vibratory Finisher with Steel Media

4 Comparison of Demonstration Results 
$\bullet$

.

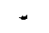

, 


\section{INTRODUCTION}

The operation and eventual decommissioning of nuclear industry facilities will generate large quantities of surface-contaminated metallic and nonmetallic waste. This waste, particularly that contaminated with transuranic (TRU) elements, will require expensive handling, interim storage and ultimate geologic disposal. Removing the surface contamination would eliminate both the expense of storing and disposing of radioactive waste and any associated risk of environmental contamination.

Vibratory finishing is a mass, surface-finishing technique that has been used commercially since 1957 to remove burrs, generate radii, improve surface finishes, and degrease and clean various metallic and nonmetallic objects (Gillespie 1976). The finishing process takes place in a vibrating tub of loose media through which flows a liquid chemical compound. The energy from the tub causes the media to scrub the surfaces of the objects, while the liquid compound flushes away the material removed by the scrubbing action. The process is effective on external and internal surfaces, in threads and in holes. The feature that has made vibratory finishing such an attractive mass-finishing technique in commercial industries is the ability to achieve reproducible results on large volumes of material with minimal operator labor requirements. This same feature makes vibratory finishing an attractive decontamination technique for the nuclear industry.

As part of the nuclear-waste management program sponsored by the Department of Energy (DOE), Pacific Northwest Laboratory (PNL) is developing vibratory finishing into a large-scale decontamination technique for processing large volumes of surface-contaminated metallic and nonmetallic waste. Pacific Northwest Laboratory is also developing the technology to 1) scaleup the vibratory-finishing process, 2) maintain process safety and effectiveness, and 3) adapt vibratory finishing to specific decontamination and exposure-reduction applications at Hanford and other DOE sites. Finally, PNL will coordinate the transfer of vibratory-finishing technology to other DOE sites and the nuclear industry in general. The specific research and development activites in which PNL is currently involved are:

- laboratory-scale studies to understand decontamination mechanisms and to optimize the decontamination process through proper selection of media, compounds and machine settings

- establishment and operation of a demonstration decontamination system

- development of solution handling systems to minimize the volume 0 ; secondary radioactive waste requiring disposal

- establishment of criticality safety limits and operating procedures for work with fissile contaminants

- transfer of technology from the commercial vibratory-finishing insusiry to the nuclear industry

- identification of future applications.

The progress of this work is presented and discussed in the following sections of this report. 


\section{VIBRATORY-FINISHING PROCESS}

The vibratory-finishing process combines a mechanical scrubbing action with a chemical cleaning action. This process takes place inside a vibratory tub that contains loose ceramic or metal media (Figure 1). The energy from the vibrating tub causes the media to scrub the surfaces of the parts to be decontaminated, while a liquid compound flushes away the material removed by the scrubbing action.

Vibratory finishing is an extremely flexible process. It can be used to remove gross radioactive contamination, paint, grease, rust, scale and other forms of dirt. The process is effective on flat-surfaced parts, the interior surfaces of pipe (Figure 2), parts with complex shapes (Figure 3), parts with threads (Figure 4) and parts with holes (Figure 5). Vibratory finishing is also effective on a variety of materials, including stainless steel, carbon steel, glass, rubber, Plexiglas, Hypalon, and other miscellaneous plastics (Figure 6).

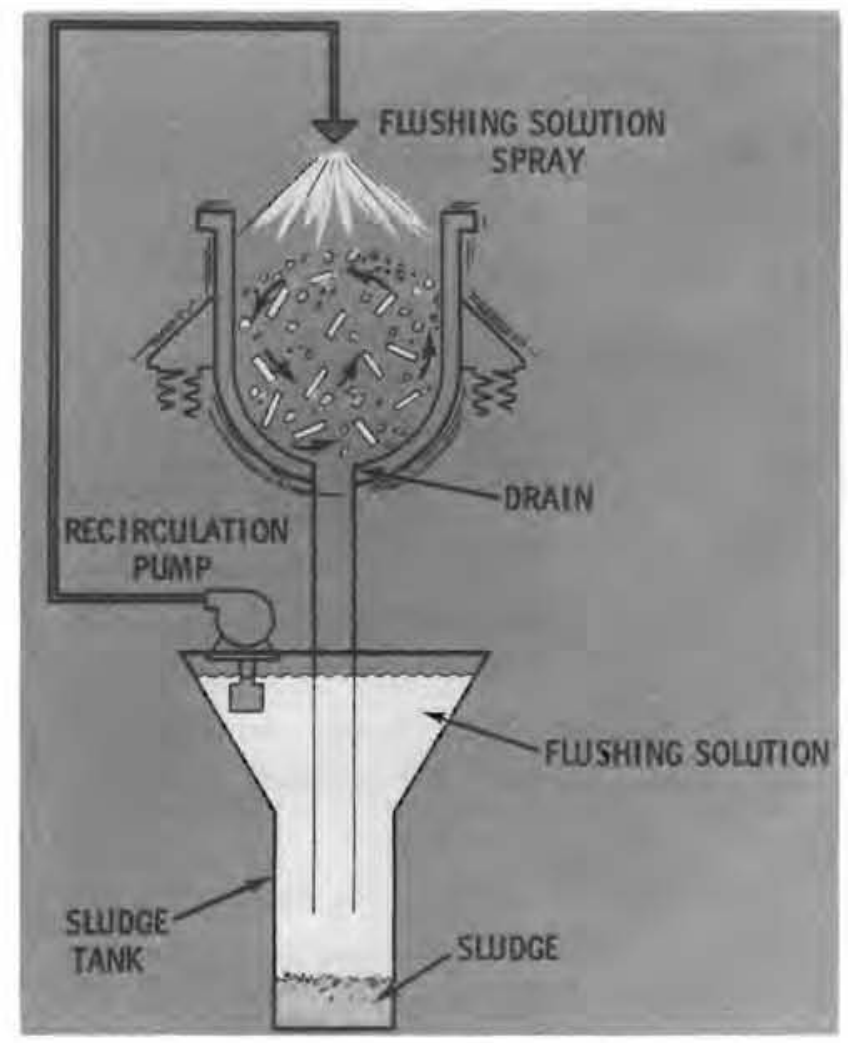

FIGURE 1. Schematic Drawing of the Vibratory-Finishing System Used for Decontamination and Pretreatment Studies 


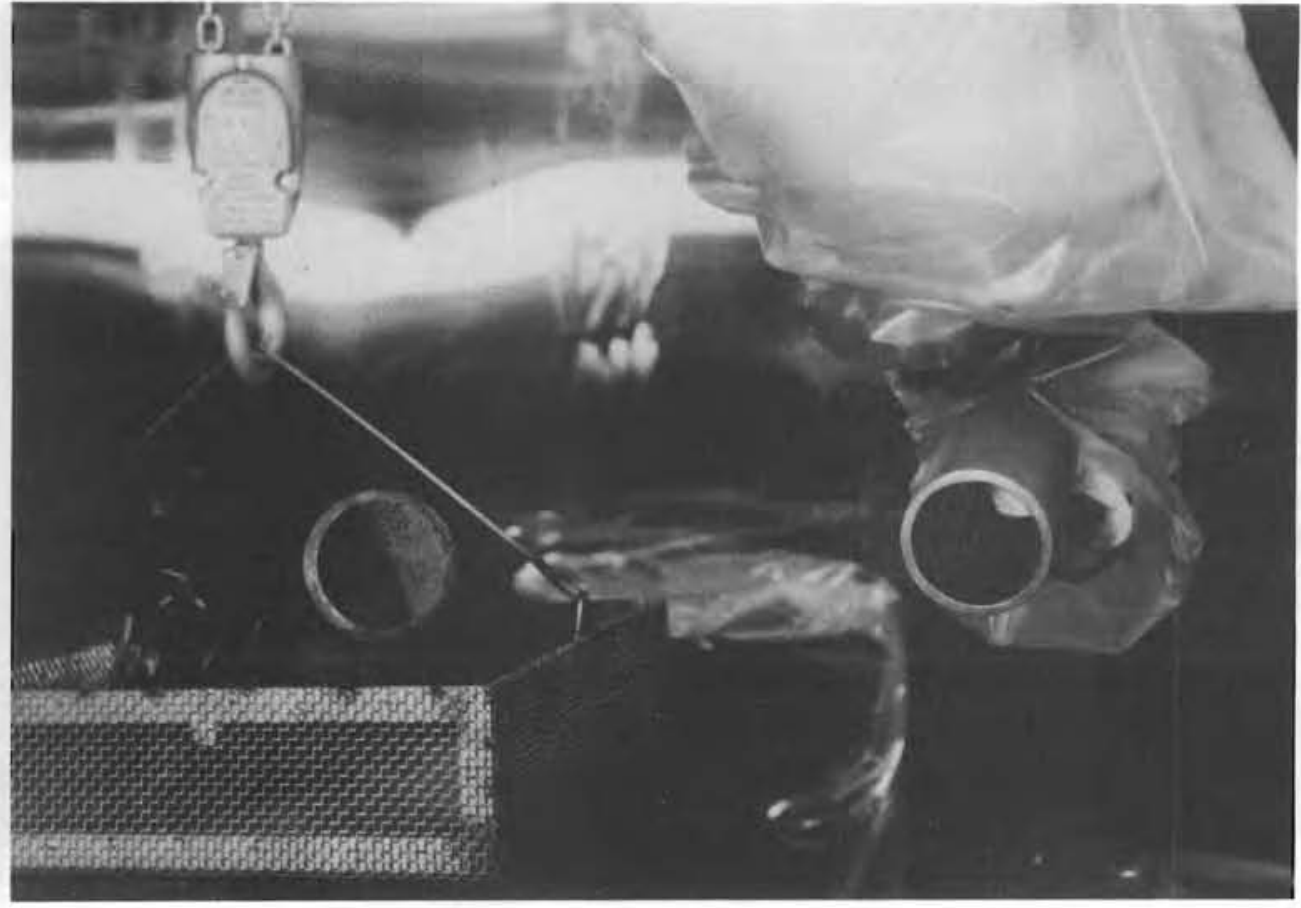

FIGURE 2. Typical Sections of Pipe Before and After Vibratory Finishing(a)

(a) Note the heavy rust buildup inside the pipe on the left without vibratory finishing and the appearance of the inside of the pipe on the right after vibratory finishing.

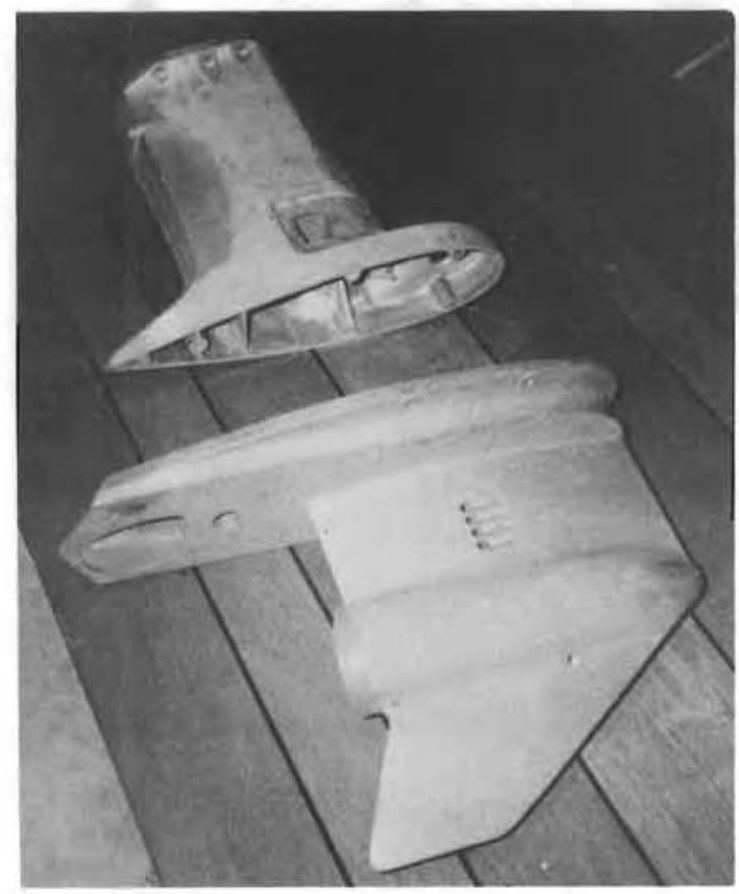

FIGURE 3. Outboard Motor Parts Deburred Using Vibratory Finishing (a)

(a) These parts demonstrate the ability of vibratory finishing to process parts with complex shapes. 


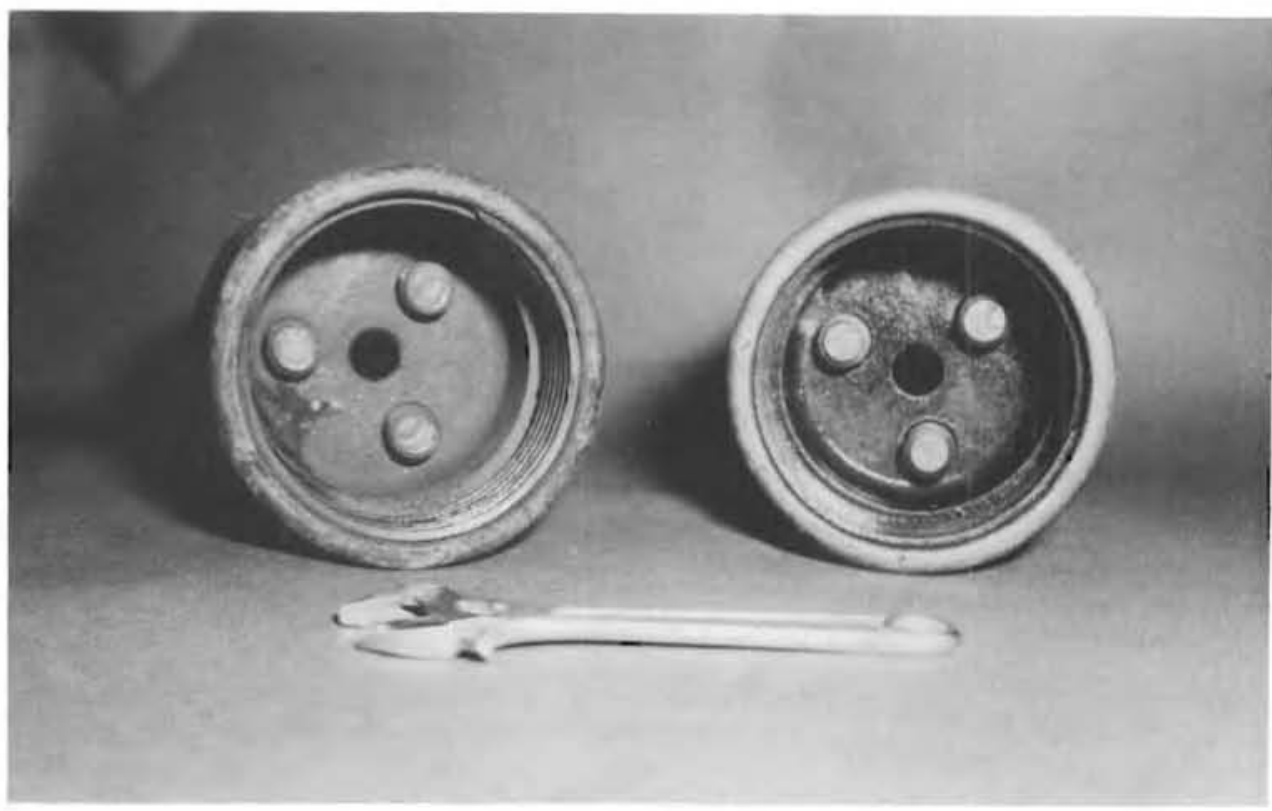

FIGURE 4. Process-Tube End Caps Demonstrate the Ability of Vibratory Finishing to Successfully Clean Threads

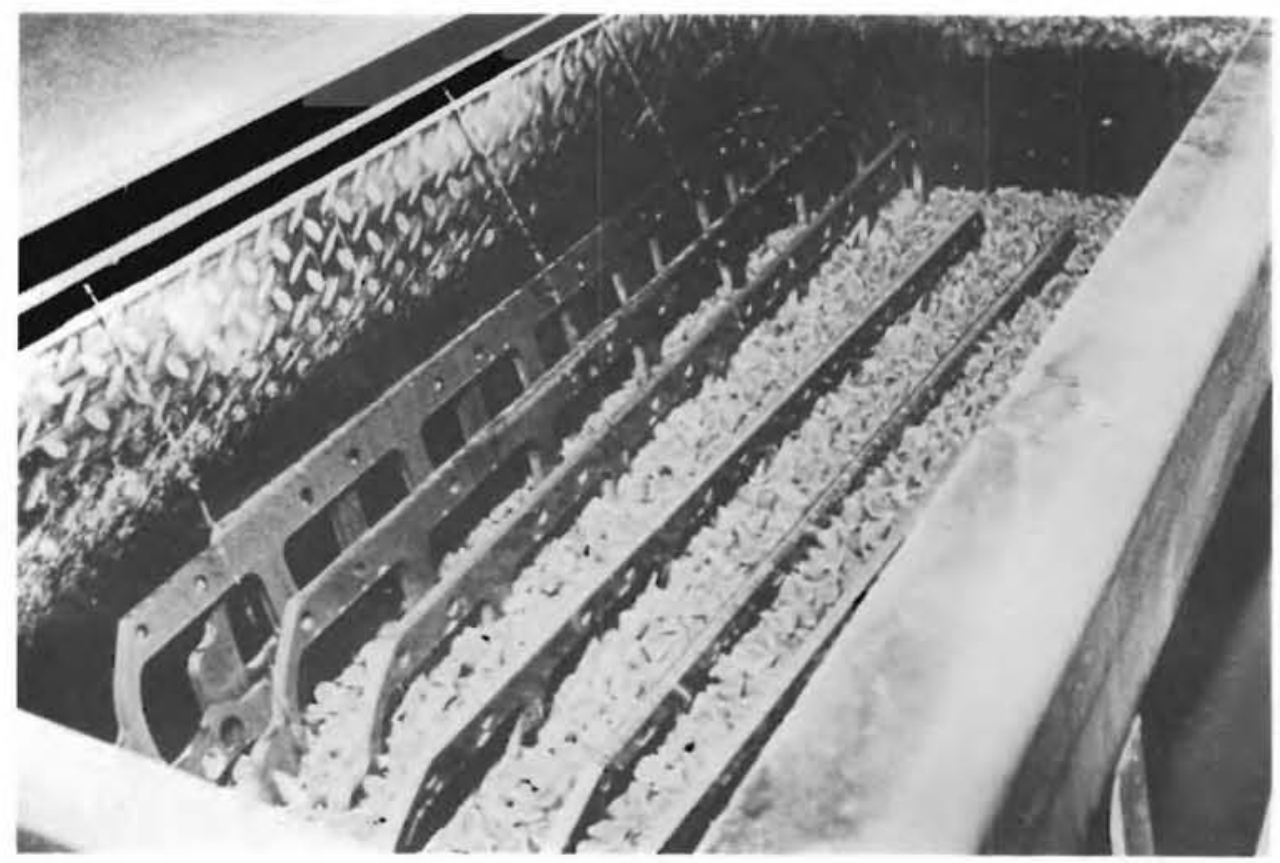

FIGURE 5. Gaskets That Demonstrate the Ability to Clean and Deburr Holes 


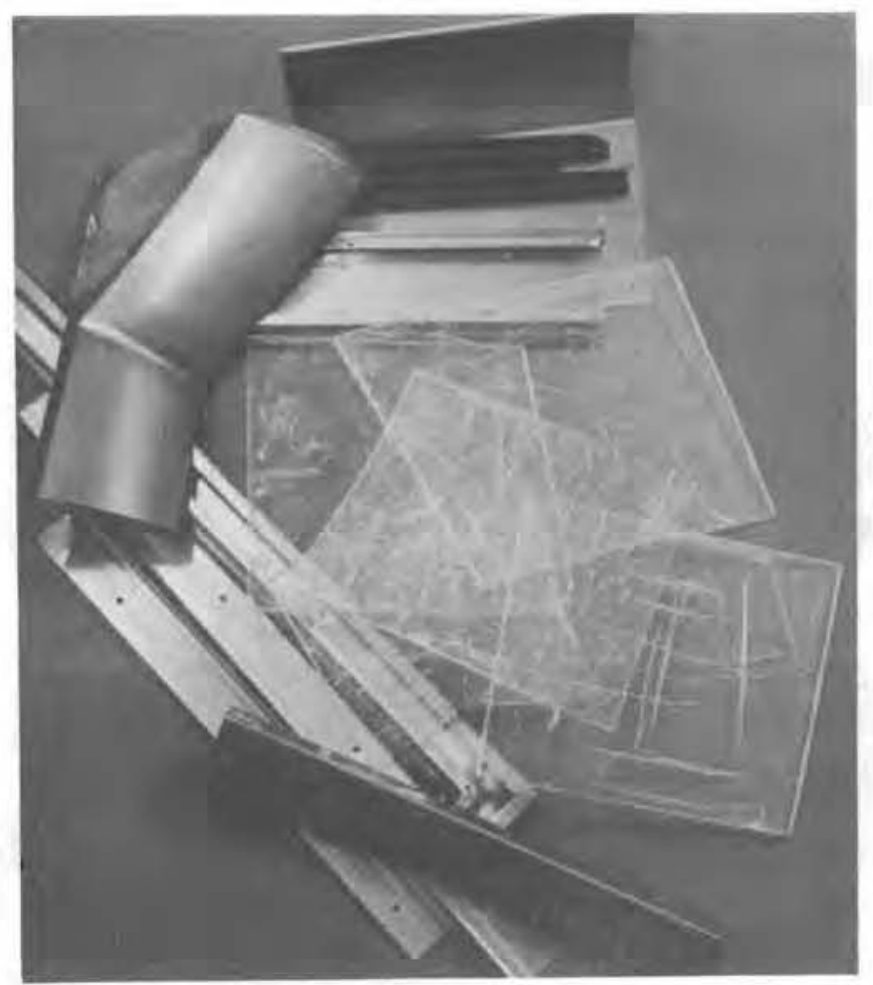

FIGURE 6. Stainless Steel, Plexiglas and Neoprene Decontaminated by Vibratory Finishing

\section{TYPES OF VIBRATORY FINISHERS}

Two types of vibratory finishers are available, the tub type and the annular type. The tub-type machine, as shown in Figure 7 , has a rectangular vibrating tub that is rounded on the bottom. The main advantage of this type of machine is its ability to process very large parts. As an example, large diesel engine blocks and up to 42-ft-long, airplane wing spars are routinely deburred using custom-built, tub-type vibratory finishers (Figure 8). The tub-type machines are available in either a batch (Figure 7) or a flow-through (Figure 9) configuration; however, it is difficult to change from one configuration to another on a given machine. The tub machines, especially the flow-through types, also occupy much more floor space than do annular machines of the same capacity.

The annular vibratory finisher has a donut-shaped vibratory tub (Figure 10). The annular machine can be equipped with an integral separator screen that separates the decontaminated parts from the media and automatically unloads the parts. This screen is particularly effective when steel media weighing $300 \mathrm{lb} / \mathrm{ft}^{3}$ are used. With the separator screen the annular system can easily be operated in either the flow-through or the batch mode. Annular machines are effective in decontaminating large quantities of small- to moderate-sized parts ( $\leq 6$ by $18 \mathrm{in.}$. The capacity of annular vibratory finishers varies from $1 \mathrm{ft}^{3}$ to greater than $50 \mathrm{ft}^{3}$. 


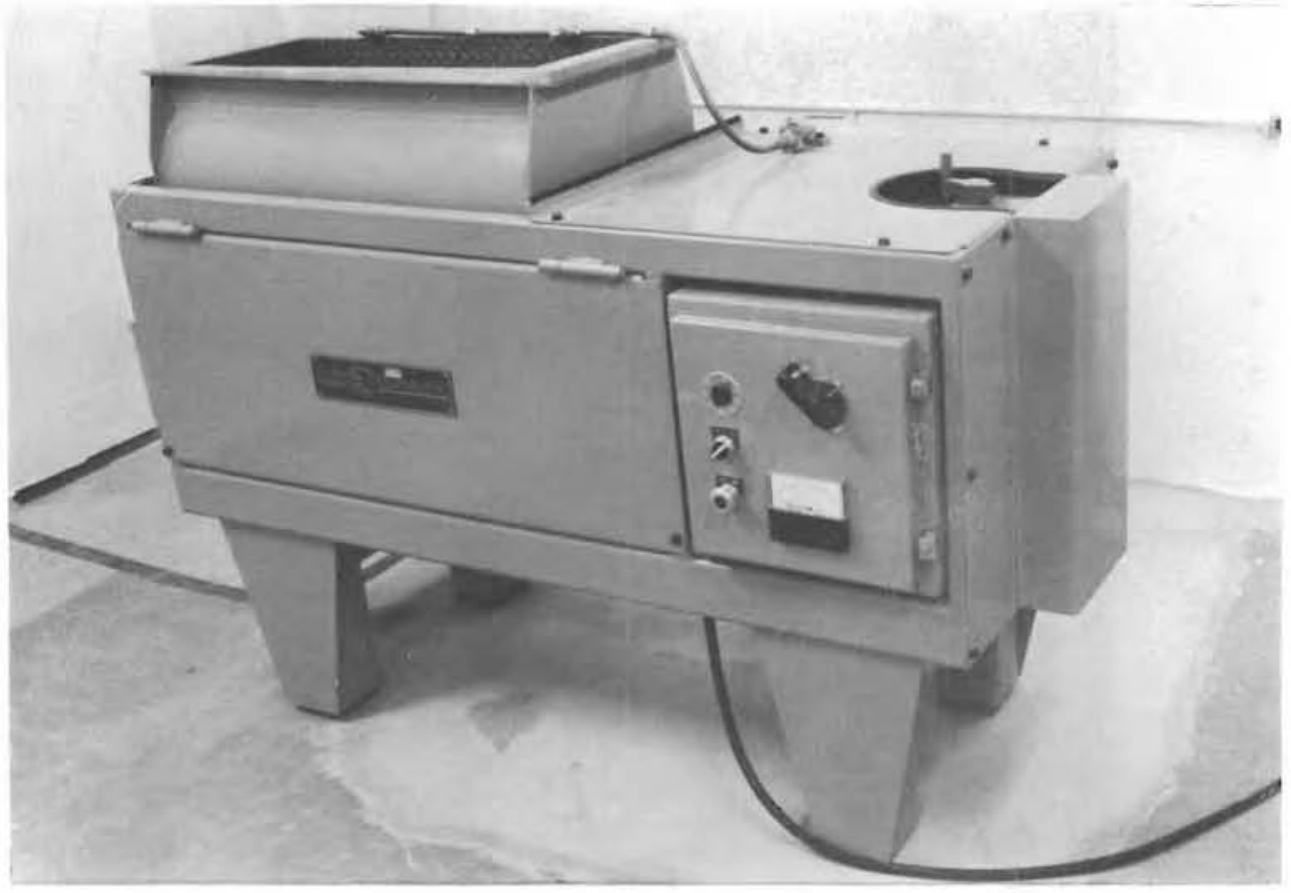

FIGURE 7. Standard Batch Tub-Type Vibratory Finisher with a 4-ft ${ }^{3}$ Capacity

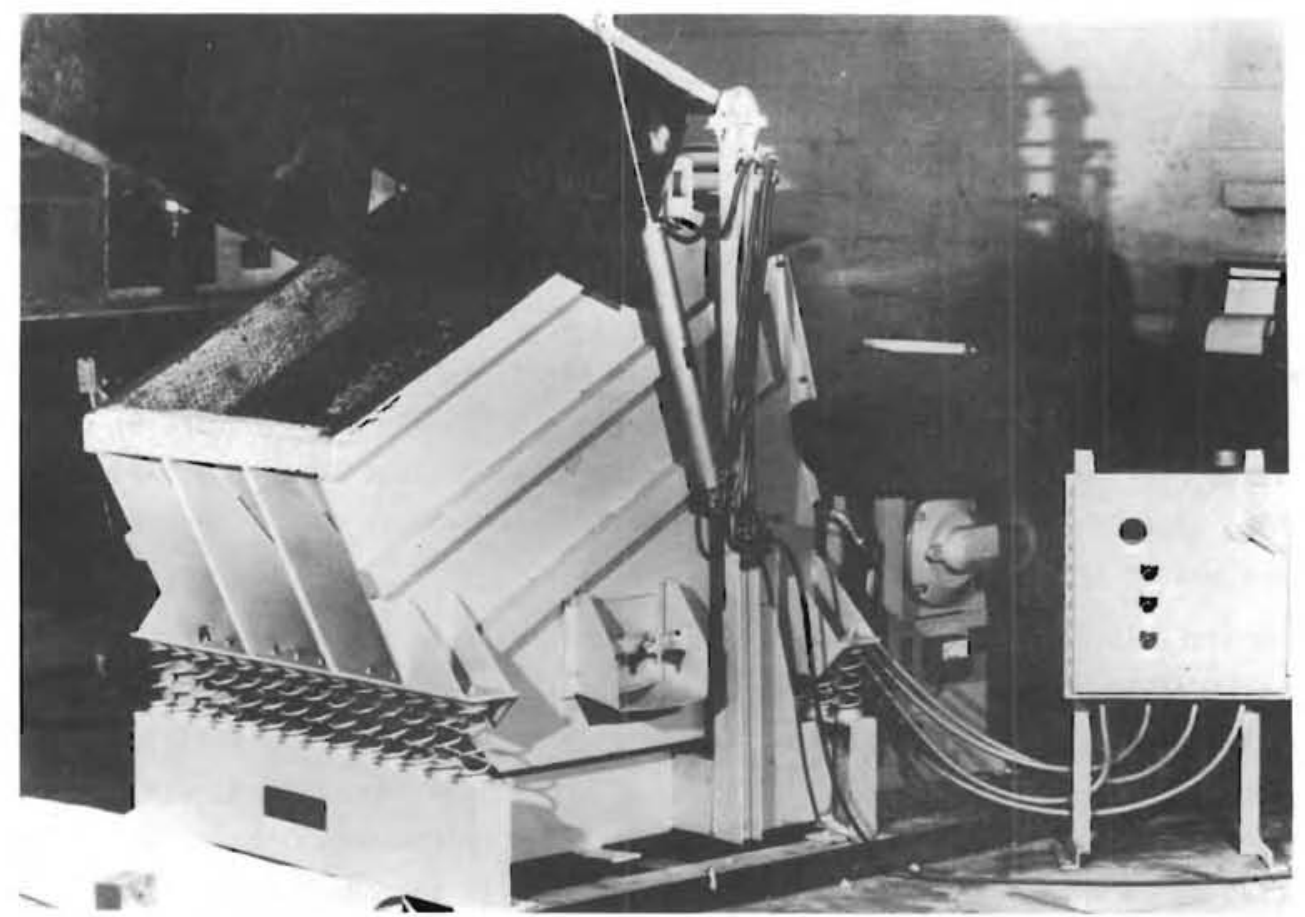

FIGURE 8. Large Batch Tub-Type Vibratory Finisher Used to Deburr Diesel Engine Blocks 


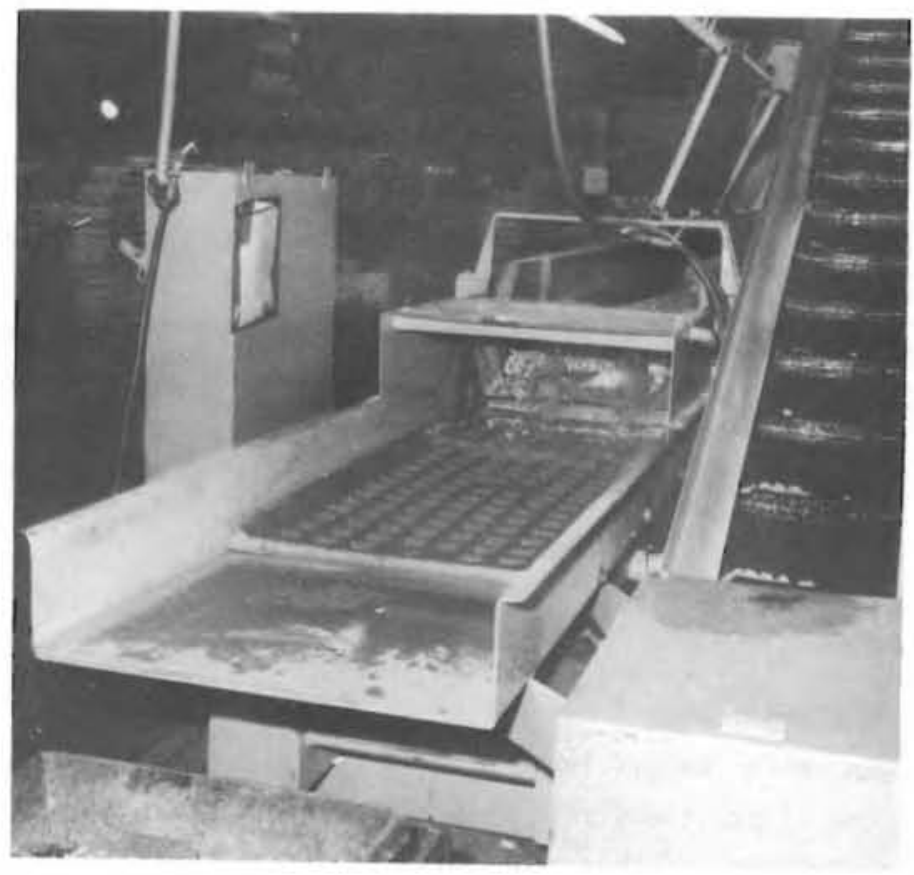

FIGURE 9. Flow-Through, Tub-Type Vibratory Finisher

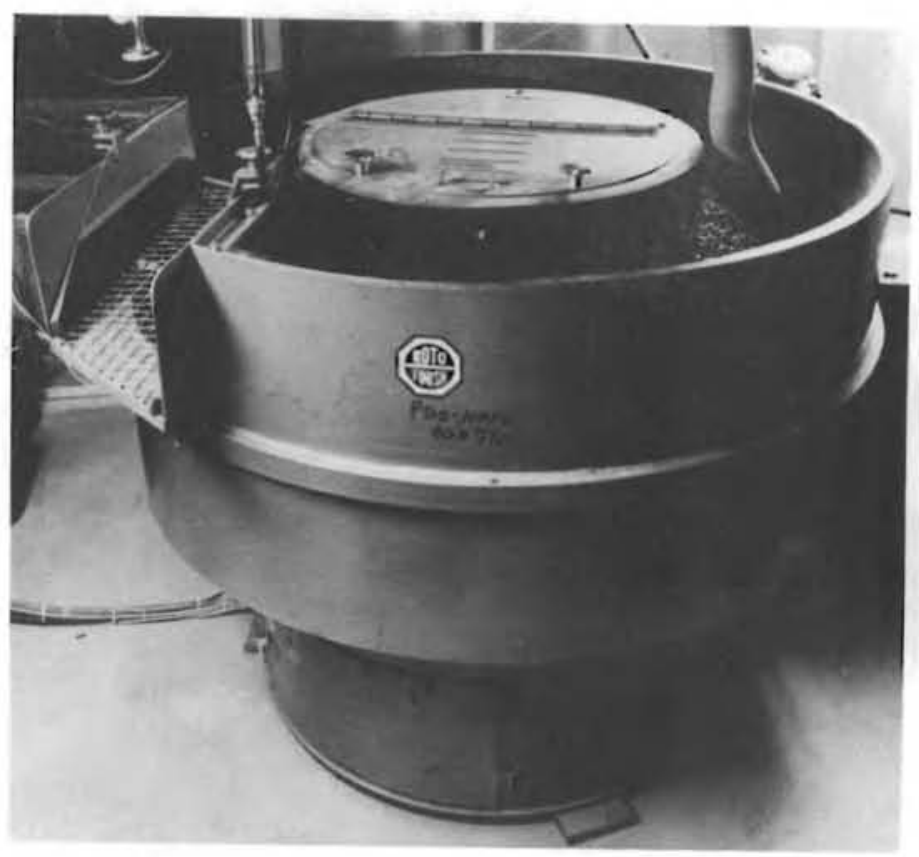

FIGURE 10. Twelve-Cubic-Foot Annular Vibratory Finisher Equipped with a Separator Screen 


\section{OPERATING THE VIBRATORY FINISHER}

The operation of the vibratory finisher is basically the same for any size or configuration. An electric motor drives a set of eccentric weights that are attached to the vibratory tub. These weights, when rotated, impart a vibration to the tub. The amplitude and frequency of vibration can be varied by adjusting the machine. The amplitude typically ranges from $1 / 64$ to $1 / 4 \mathrm{in}$. and is varied by changing the angle of the weights. (a) The frequency can range from 750 to $2150 \mathrm{vpm}$ and is varied by changing the angular velocity of the weights. By varying amplitude and frequency, various feed rates, processing rates and surface finishes can be obtained. (b)

MEDIA

The media used for vibratory finishing are available in a wide variety of sizes, shapes and materials. Of the available materials, ceramic and metal were shown to be the most suitable for decontamination applications. Plastic and ceramic media are abrasive; aluminum oxide or silicon carbide (the abrasive) is imbedded in a resin or ceramic matrix. This material is then formed into pieces of precise sizes, shapes and hardnesses. Typical shapes include triangles, cylinders, arrowheads, spheres and stars (Figure 11). The dimensions of these shapes vary from $3 / 16 \mathrm{in}$. to several inches. The type of abrasive and the hardness of the matrix determine the cutting rate of the media, which can range from 0.01 to $0.06 \mathrm{wt} \%$ of the media/h. The higher the cutting rate the faster the media will decontaminate; however, a high cutting rate results in more secondary waste due to a high self-wear rate. Fast-cutting media also produce a rough mat finish on the decontaminated material. While media with a low cutting

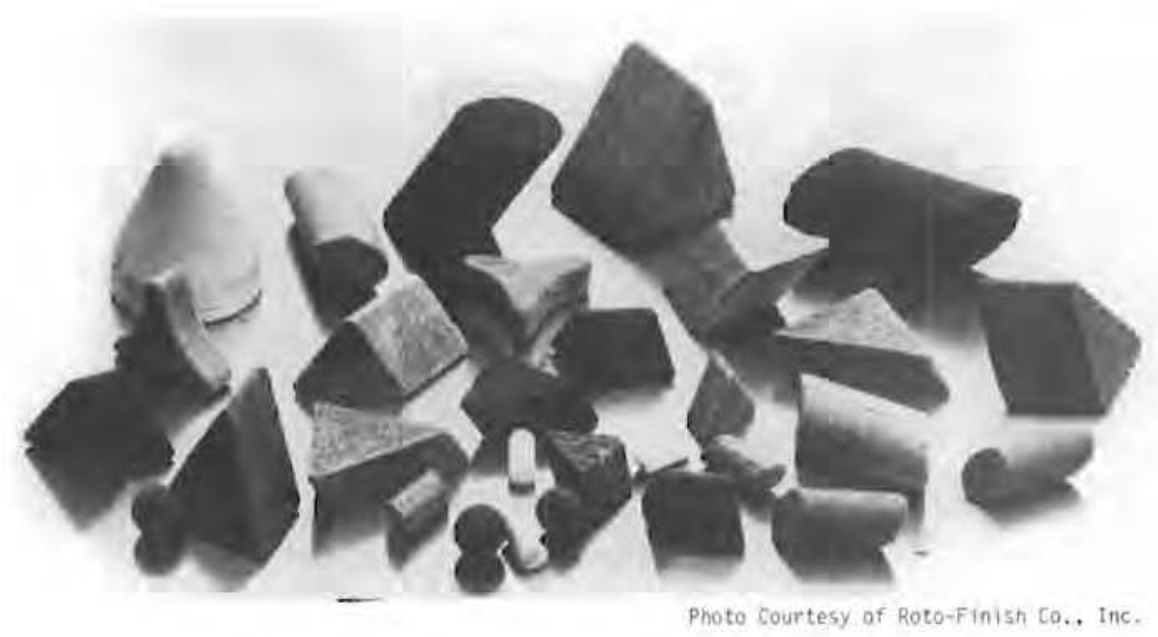

FIGURE 11. Ceramic Media Used in Vibratory Finishing

(a) Technical Information, EDV-4, Vibratory Finishing Machine, Electro Deburring Co., Inc., Oak Creek, WI.

(b) Technical Information, Roto Tech Reports, Roto-Finish Co., Inc., Kalamazoo, MI. 
rate generally decontaminate slower, they generate less secondary waste due to the low selfwear rate. Slow-cutting media also produce a finer finish on the decontaminated material. The characteristics of slow- and fast-cutting media are summarized in Table 1.

Metal media are used for cleaning and burnishing in the metal-finishing industry. The media are normally made from case-hardened carbon steel, but they are available in stainless steel and zinc. There is no abrasive present in metal media. As with ceramic media, metal media are available in a variety of sizes and shapes. Typical shapes for metal media are spheres, oval balls, diagonals, diamonds, cones, pins and ballcones (Figure 12). The dimensions of metal media vary from $1 / 6$ to $11 / 16$ in. Metal media have an extremely low cutting rate $(<0.002 \mathrm{wt} \% / \mathrm{h})$ and virtually no self-wear. The secondary waste produced by vibratory finishing with metal media consists only of the material removed from the surfaces of the decontaminated items such as paint, rust, scale, dirt and radioactive contamination.

TABLE 1. Characteristics of Slow- and Fast-Cutting Media

\begin{tabular}{|c|c|c|c|c|}
\hline \multirow[b]{2}{*}{ Media } & \multicolumn{4}{|c|}{ Characteristics } \\
\hline & $\begin{array}{l}\text { Media } \\
\text { Wear }\end{array}$ & $\begin{array}{c}\text { Decontamination } \\
\text { Rate }\end{array}$ & $\begin{array}{l}\text { Secondary Waste } \\
\text { Produced }\end{array}$ & Finish \\
\hline Fast-cutting & high & fast & large & rough \\
\hline Slow-cutting & low & slow & small & fine \\
\hline
\end{tabular}

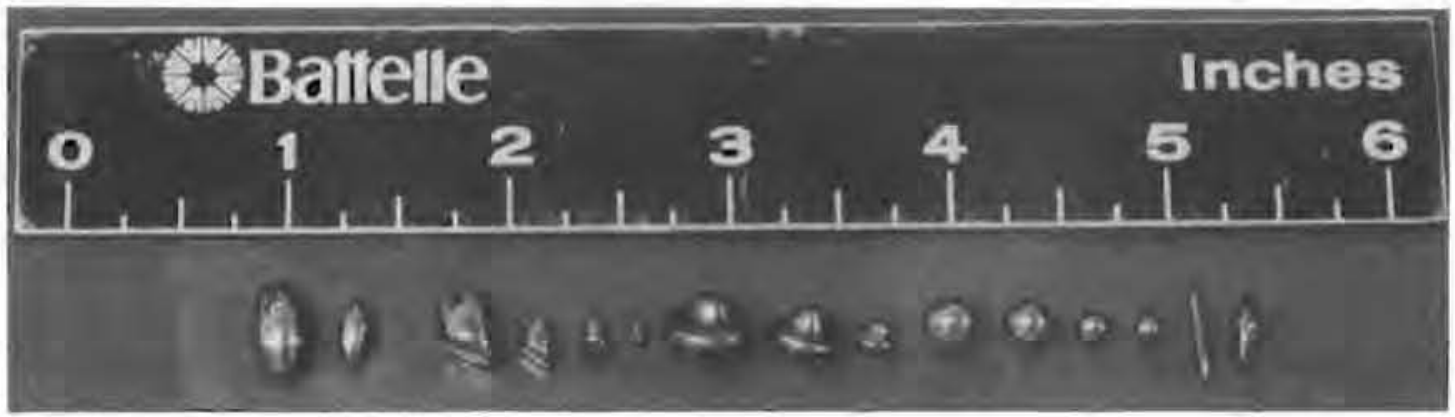

FIGURE 12. Metal Media Used for Vibratory Finishing

\section{MEDIA SELECTION}

Several factors must be considered when selecting a media, including the desired surface finish, the configuration and size of the parts to be decontaminated, and the amount of secondary waste that can be tolerated. The size and shape of the media selected will depend on the size, shape and configuration of the part and on the presence and size of holes in the part. The media must be able to reach recesses and holes in the part without becoming lodged. The media must also be selected so as to allow separation of the media from the parts. This can be done mechanically by using vibrating screen decks (Figures 9 and 10) or magnetically. 
Decontamination requires generation of as little secondary waste as possible. For this reason when decontamination is the sole objective, metal media should be used. However, if the item being decontaminated will be reused and has specific surface-finish requirements or dimensional tolerances that must be preserved, media that will fulfill these requirements must be selected.

\section{COMPOUND}

To complete vibratory finishing, a liquid compound is added to the vibrating tub and media. The main purpose of the compound is to lubricate and clean. However, special compounds may be used that perform additional functions such as removing paint, grease, rust or scale. Corrosion inhibitors or even chemical polishing solutions can be added for other special effects. Very fine-mesh, abrasive particles may also be added to the liquid compound to increase the amount of material removed. The compound is sprayed onto the top of the media, percolates through the media, and flows through a drain in the bottom of the tub. The flow of the compound through the media flushes the debris generated by vibratory finishing along with the radioactive material from the tub and concentrates it in a liquid-waste collection tank. Typical flow rates are $2 \mathrm{gal} / \mathrm{h} / \mathrm{ft}^{3}$ of machine capacity. 


\section{VIBRATORY-FINISHING DECONTAMINATION STUDIES}

This section describes the progression of vibratory-finishing studies that led to the eventual decontamination of a plutonium-contaminated glove box. Vibratory finishing was first tested as a pretreatment technique for electropolishing. The success of those initial tests led to the installation of a vibratory finisher at Hanford's N-Reactor for further tests. Later the vibratory finisher was installed in Hanford's 231-z Building, where: 1) the use of steel media was tested, 2) the decontamination of TRU-contaminated objects was both tested and demonstrated and 3 ) the decontamination of nonmetallic objects was tested.

\section{INITIAL TESTS}

Vibratory finishing was first tested as a technique for pretreating surfaces before decontaminating them by electropolishing, which requires clean, conductive surfaces (Allen et al. 1978). The first test load consisted of 16 contaminated, carbon stee 1 pipe clamps (Figure 13) from the Hanford N-Reactor with a total weight of $62 \mathrm{lb}$. These were processed in a 4-ft $\mathrm{ft}^{3}$,

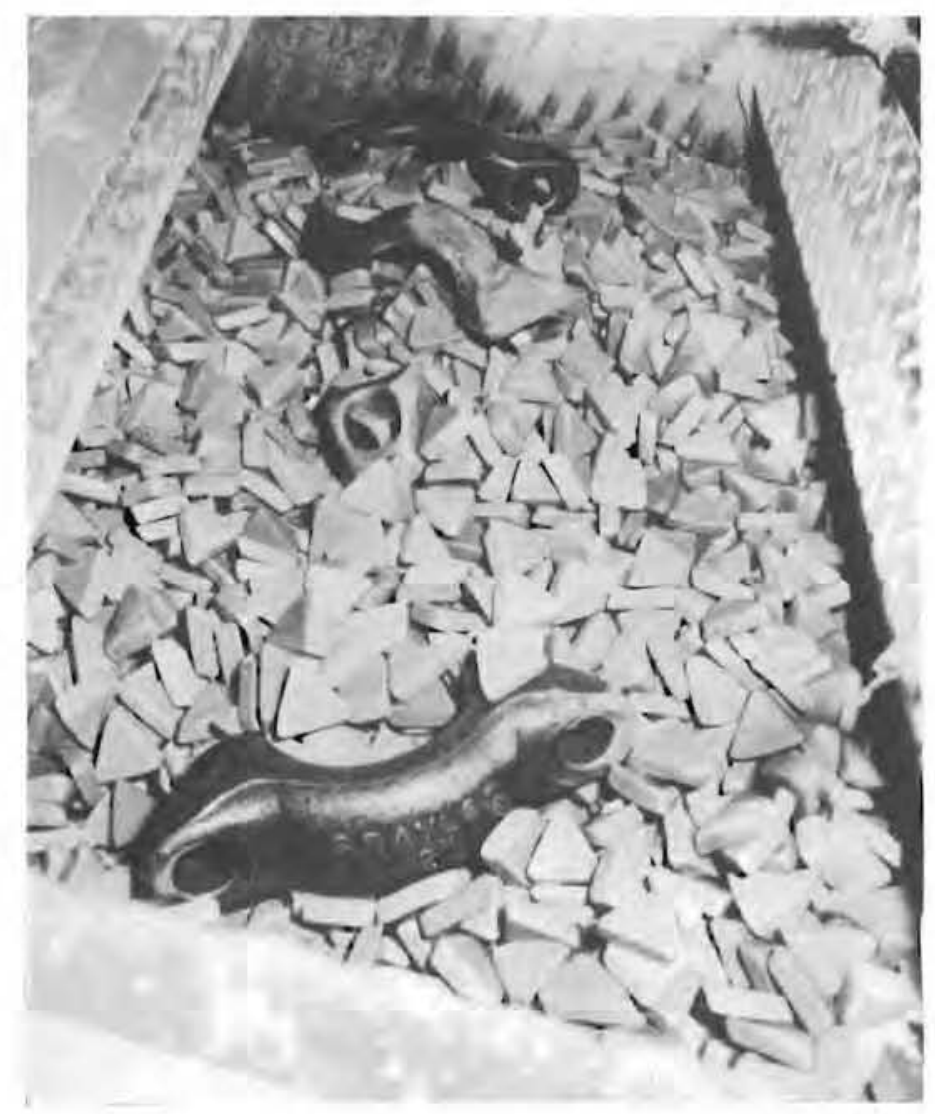

FIGURE 13. Pipe Clamps from the Hanford N-Reactor Being Decontaminated in a Vibratory Finisher 
tub-type vibratory finisher with ceramic media and a detergent compound. The initial radiation level of the clamps averaged about $100 \mathrm{mrad} / \mathrm{h}$, with most of the contamination associated with a heavy rust layer. Four hours of vibratory finishing were sufficient to remove this corrosion layer and leave a clean, bright surface ready for electropolishing. In addition, the average radiation level was reduced to about $1 \mathrm{mrad} / \mathrm{h}$.

The second test load consisted of 150 contaminated, carbon steel rings ( 3 in. in 00 by 2 in. in ID by $0.4 \mathrm{in.} \mathrm{thick;} \mathrm{see} \mathrm{Figure} \mathrm{14).} \mathrm{These} \mathrm{were} \mathrm{processed} \mathrm{in} \mathrm{the} \mathrm{same} \mathrm{vibratory} \mathrm{fin-}$ isher as the first test load using the same media. The rings weighed a total of $66 \mathrm{lb}$ and had an initial radiation reading of 3 to $6 \mathrm{mrad} / \mathrm{h}$. This was reduced to less than $0.5 \mathrm{mrad} / \mathrm{h}$ after four hours of vibratory finishing. Most of the remaining contamination was in small, inaccessible grooves. However, this is not a problem as media can be obtained that would decontaminate these areas.

These two tests demonstrated that vibratory finishing can successfully remove gross beta/ gamma contamination as well as rust and other surface material to produce surfaces that are clean and ready for final decontamination by electropolishing. (In this instance no further decontamination was required since the decontaminated material was intended for reuse on $\mathrm{N}$-Reactor; therefore, exposure reduction and not complete decontamination was required.) Furthermore, even after decontaminating this material, the media and the tub walls were found to be essentially uncontaminated. The same abrasive action that removes the contamination also keeps these surfaces clean. The contamination, rust, paint, spent abrasive, etc., are continuously flushed out of the vibratory finisher into a waste container, where they can be collected and concentrated for disposal. Thus, in addition to preparing surfaces for final decontamination by electropolishing, vibratory finishing is itself an effective decontamination technique.

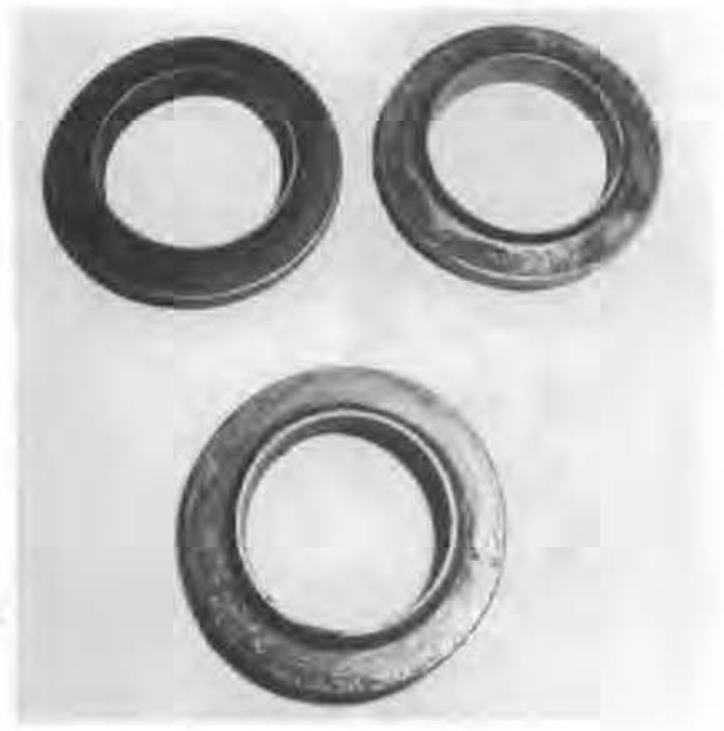

FIGURE 14. Carbon Steel Rings from the Hanford N-Reactor Decontaminated by Vibratory Finishing 


\section{N-REACTOR DEMONSTRATION}

Based on the success of the initial testing of vibratory finishing as a decontamination technique, the 4- $\mathrm{ft}^{3}$ vibratory finisher was temporarily installed at the Hanford N-Reactor for intensive testing of its decontamination capabilities using contaminated components generated by the reactor's summer outage. Ceramic media and a 10\%-sodium-hydroxide compound were used during the $\mathrm{N}$-Reactor demonstration. The compound was recirculated through the machine at $7 \mathrm{gal} / \mathrm{h}$. These tests showed that the vibratory finisher effectively removes gross contamination and concentrates the contamination in a sludge tank. For example, process-tube end caps and inserts that were treated in the vibratory finisher (Figure 15) were decontaminated to $15 \mathrm{mrad} / \mathrm{h}$ compared to $24 \mathrm{mrad} / \mathrm{h}$ for inserts treated by standard chemical decontamination methods. Cost comparisons performed by United Nuclear Corporation, operator of the N-Reactor, indicated that the use of vibratory finishing, as opposed to regular chemical decontamination, on process-tube end caps and inserts could save them over $\$ 8000 / \mathrm{yr}$.

During the $\mathrm{N}$-Reactor demonstration a total of $30.6 \mathrm{ft}^{2}$ of contaminated surface area were processed in 30 hours, producing $1.4 \mathrm{ft}^{3}$ of secondary waste. Items that were decontaminated included carbon steel process-tube end caps and inserts (Figure 15), an electric pump motor housing (Figure 16) and various hand tools (Figure 17). The most dramatic reduction in radiation level occurred on an end cap, where the level was reduced from 1500 to $200 \mathrm{mrad} / \mathrm{h}$ in four hours of processing time.

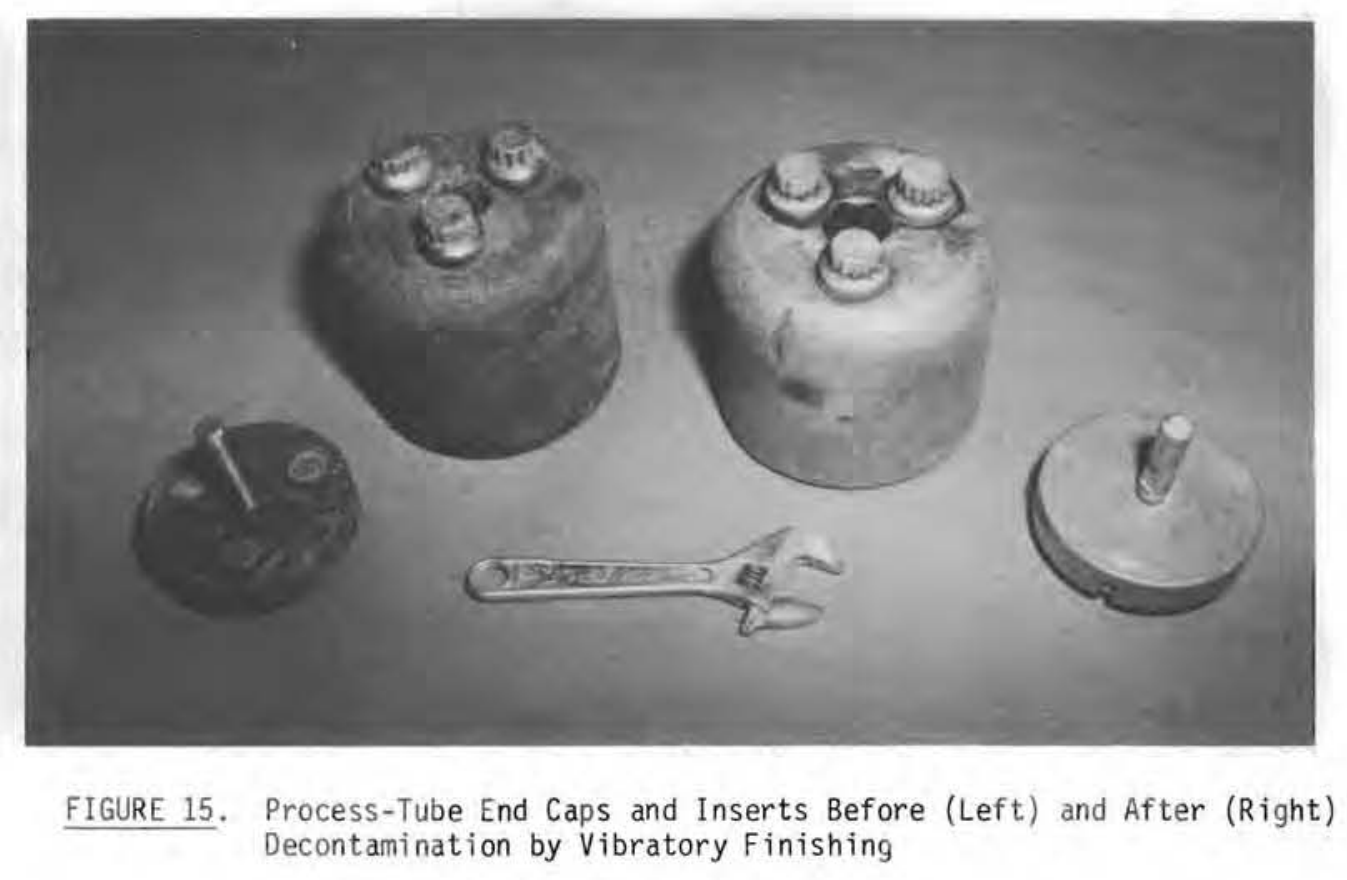




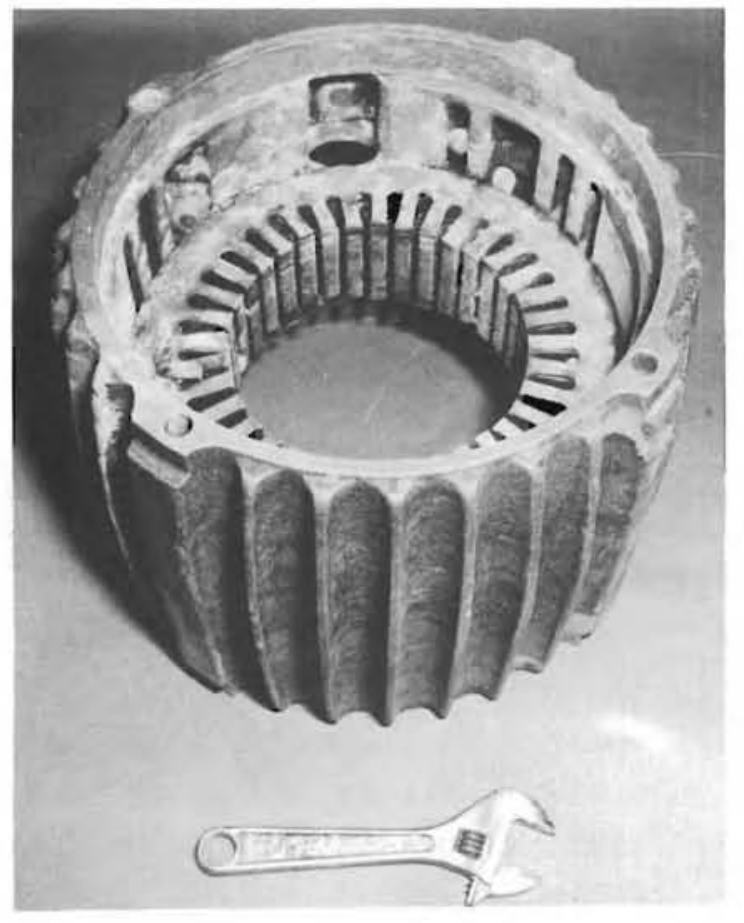

FIGURE 16. Electric Pump Motor Housing from a Hanford $\mathrm{N}$-Reactor Valve Decontaminated by Vibratory Finishing

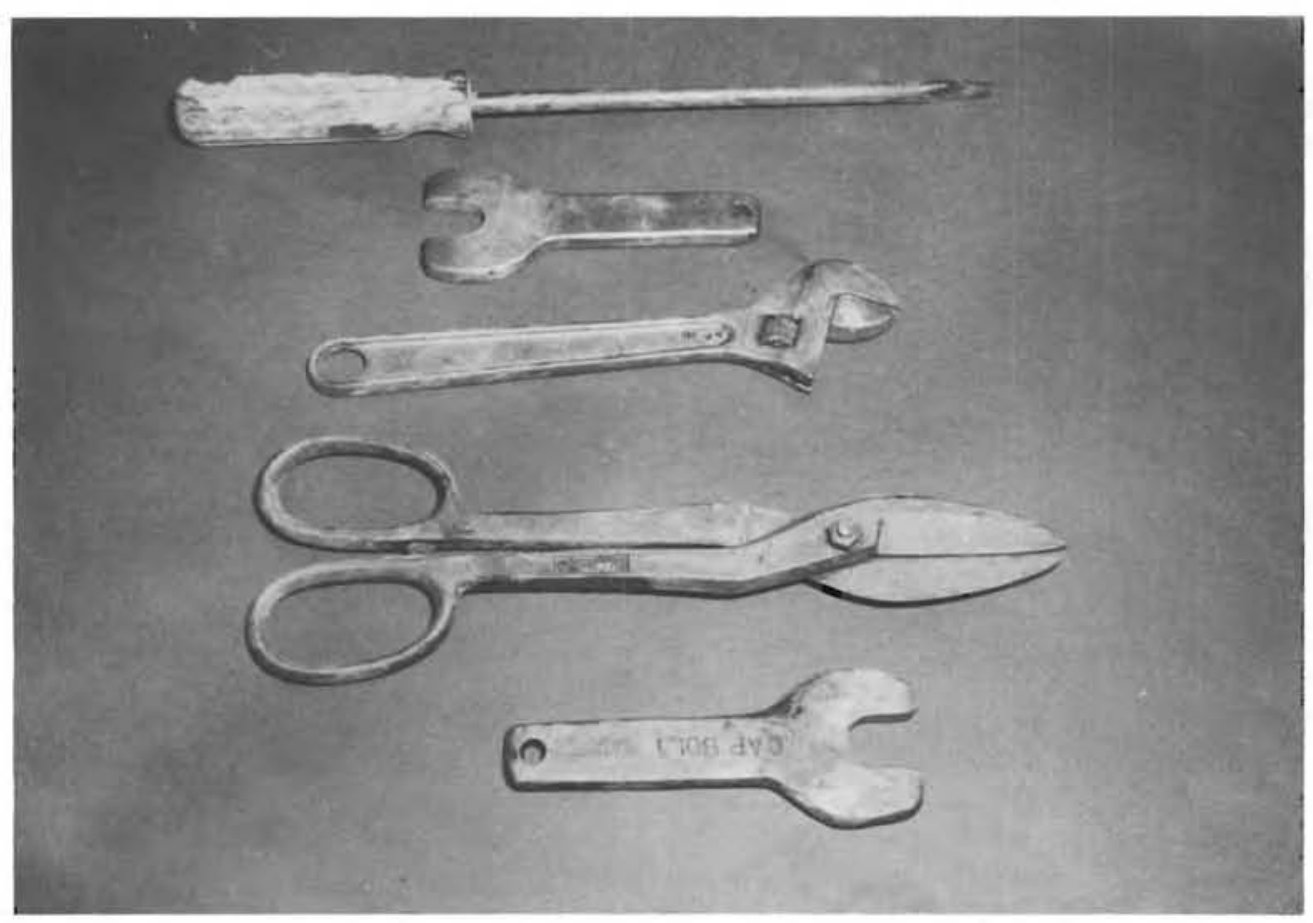

FIGURE 17. Hand Tools from Hanford N-Reactor Decontaminated by Vibratory Finishing 
Another item processed was a ball-channel inspection tool (Figure 18) made of stainless steel with rubber tubing covering about two-thirds of its length. The radiation level on the too 1 was reduced from 1500 to $70 \mathrm{mrad} / \mathrm{h}$, with a $300-\mathrm{mrad} / \mathrm{h}$ hot spot on the tubing. This demonstrated the ability to decontaminate both metallic and nonmetallic materials simultaneously by vibratory finishing.

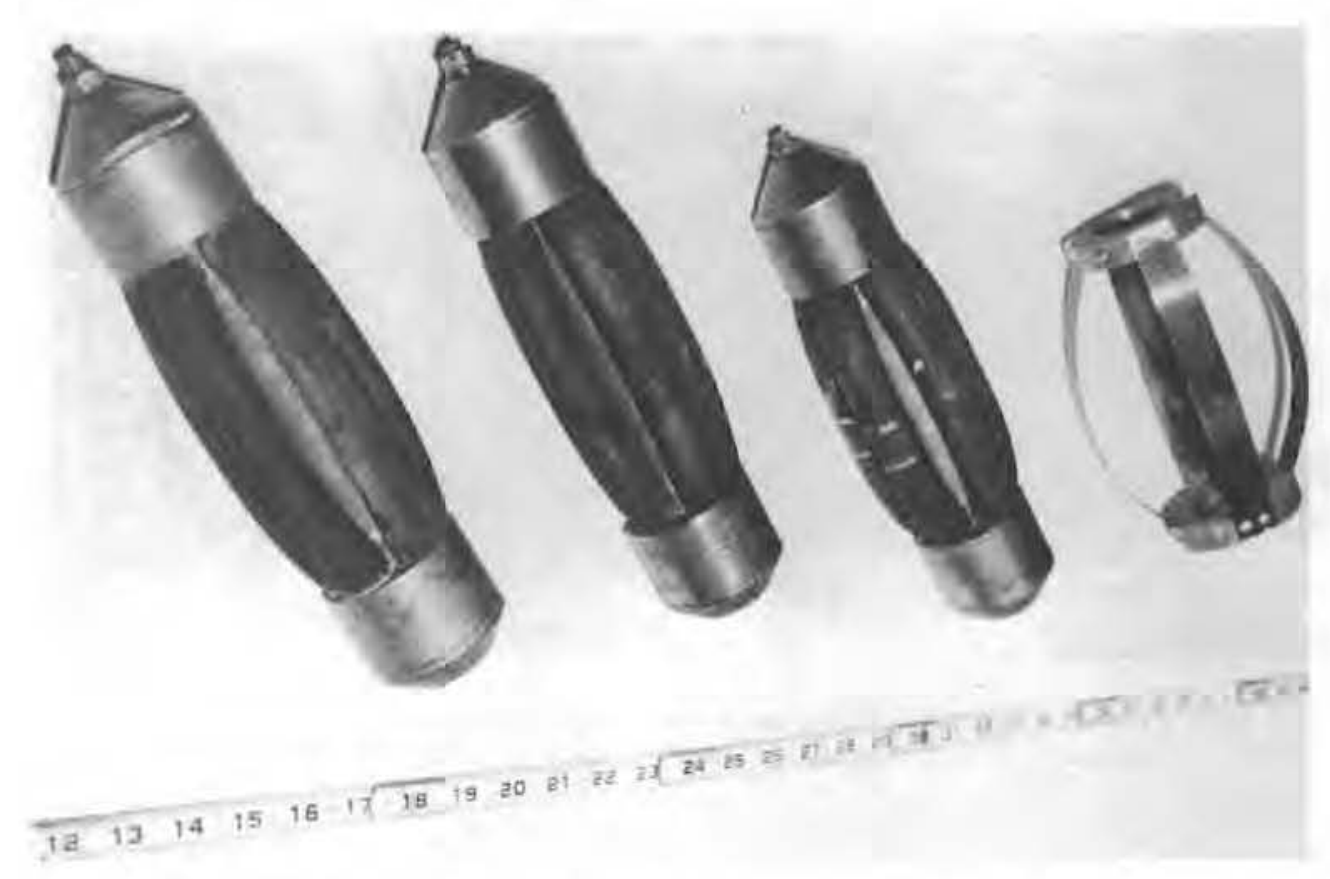

FIGURE 18. Ball-Channel Inspection Tools Used at Hanford N-Reactor After Decontamination by Vibratory Finishing

\section{USE OF STEEL MEDIA}

When the N-Reactor demonstration was completed, the vibratory finisher and associated sludge tank were installed in a stainless steel, walk-in glove box located in the Hanford 231-Z Building (Figure 19) for further testing using beta/gamma-contaminated items from N-Reactor. Most of these tests were conducted using low-wear-rate steel burnishing media rather than the ceramic-type deburring media used in the previous vibratory-finishing tests. The results from the tests with metal media were very encouraging. The steel media rapidly removed grease, rust, and both latex and enamel paint. In addition, their burnishing action was almost as effective as the ceramic media's cutting action in removing most of the gross surface contamination. More importantly, the surfaces were cleaned and decontaminated with essentially no secondary waste generated from wear of the steel media.

The beta/gamma-contaminated mild-steel fuel spacers (Figure 20), process-tube end caps, and process-tube inserts were vibratory-finished in the steel media for a total of 10 hours using a commercial, liquid, burnishing compound. This test (Table 2) showed that average surfacecontamination levels were substantially reduced and that most of this reduction occurred during 


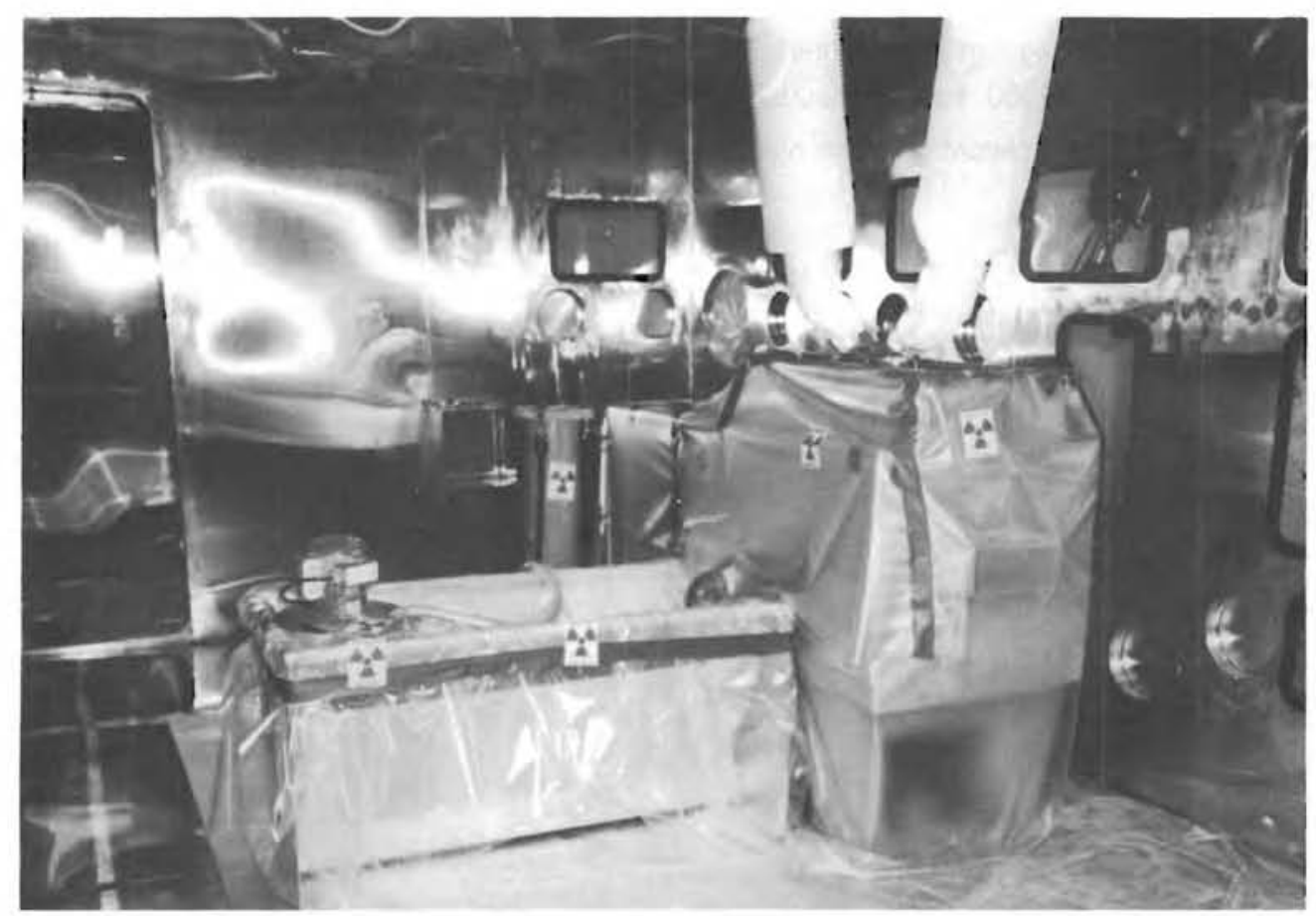

FIGURE 19. Four-Cubic-Foot, Tub-Type Vibratory-Finishing System with Recirculating Compound System Installed in the Stainless Steel, Walk-in Glove Box
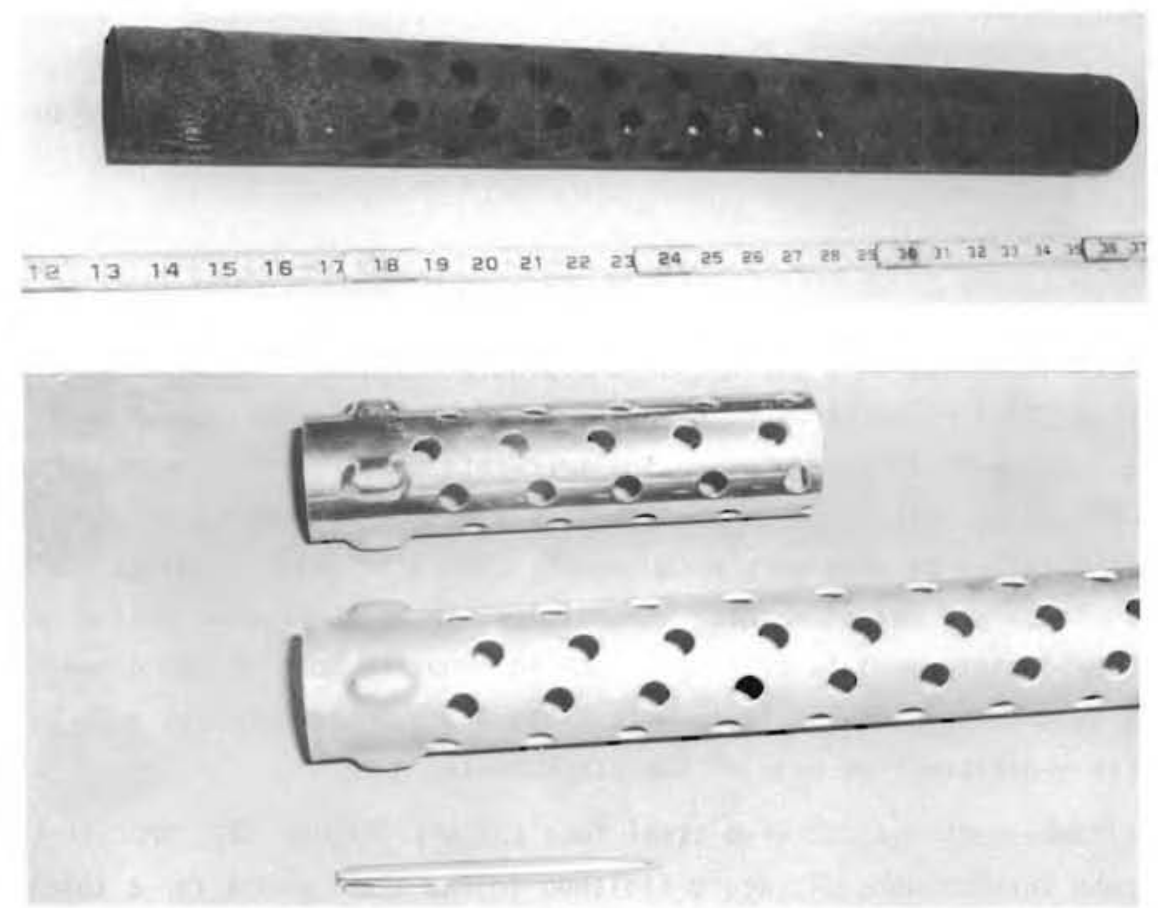

FIGURE 20. Fuel Spacers from Hanford N-Reactor Before (Top) and After (Bottom) Decontamination by Vibratory Finishing 
TABLE 2. Decontamination of Beta/Gamma-Contaminated Components Using Vibratory Finisher with Steel Media

\begin{tabular}{|c|c|c|c|c|c|c|c|c|}
\hline \multirow[b]{3}{*}{ Component } & \multicolumn{8}{|c|}{ Fixed Contamination, $\mathrm{mrad} / \mathrm{h}$} \\
\hline & $\operatorname{In} i$ & & After & $h$ & Afte & $2 h$ & Afte & $10 \mathrm{~h}$ \\
\hline & Outside & Inside & Outside & Inside & Outside & Inside & Outs ide & Inside \\
\hline Fuel Spacer & 800 & 10,000 & 20 & 100 & 25 & 75 & 15 & 70 \\
\hline Fuel Spacer & 300 & 1,500 & 35 & 45 & 25 & 25 & 20 & 80 \\
\hline End Cap & 200 & 5,000 & 20 & 700 & 10 & 100 & 10 & 120 \\
\hline End Cap & 200 & 1,000 & 10 & 30 & 10 & 28 & 8 & 15 \\
\hline Insert & 500 & --- & 300 & -- & 250 & --- & 200 & --- \\
\hline Insert & 150 & --. & 100 & --- & 130 & -.- & 100 & --- \\
\hline Steel media & & & $\begin{array}{r}2,0 \\
\text { (count }\end{array}$ & nin) & $\begin{array}{r}1, \\
\text { (coun }\end{array}$ & nin) & $\begin{array}{r}4 \\
\text { (coun }\end{array}$ & $\operatorname{nin)}$ \\
\hline
\end{tabular}

the first hour of processing. Moreover, even after only one hour of processing, all components were either nonsmearable or had such low levels of smearable contamination ( $<1000$ counts/min) as to substantially facilitate subsequent handling and final decontamination operations.

The effects of a free abrasive on the decontamination capabilities of the steel media were investigated by adding $1 \mathrm{~kg}$ of $\mathrm{AlO}_{2}$ abrasive at the end of the 10-hour run and then processing for an additional hour. The added abrasive further reduced the fixed contamination levels by about $60 \%$, but the resulting secondary waste was an extremely fine powder that was very difficult to handle. It should be noted that although the steel media did not generate any secondary waste, it did become slightly contaminated (see Table 2). However, this contamination was reduced to insignificant levels by the media's self-cleaning action as the run progressed.

\section{TRANSURANIC DECONTAMINATION TESTS}

The first test of the vibratory finisher with plutonium-contaminated material was conducted using four pieces of stainless steel from Hanford glove boxes and two pieces of stainless steel (coated on one side with difficult-to-decontaminate epoxy) from Rocky Flats glove boxes. Steel media and a paint-stripper compound were used for this test. The results (see Table 3) showed that the vibratory finisher with the steel media very effectively removes plutonium contamination. As in the case of beta/gamma-contaminated material, most of the decontamination occurred within the first hour of processing and included complete elimination of the smearable contamination. Moreover, the decontamination process was equally effective for the epoxy-coated surfaces, illustrating the ability of vibratory finishing to decontaminate selected, nonmetallic TRU-contaminated waste.

A follow-up test using the same steel media and compound was conducted to verify the initial test results and to obtain detailed decontamination-rate data for the first hour of decontamination. Ten plutonium-contaminated, stainless steel, Hanford glove-box pieces were used. The glove-box pieces were processed for $60 \mathrm{~min}$ in the steel media followed by an additional 60 min of processing in fast-cutting ceramic media with the same compound. The results are 
TABLE 3. Decontamination of Plutonium-Contaminated Glove-Box Sections Using Vibratory Finisher with Steel Media

\begin{tabular}{|c|c|c|c|c|c|c|}
\hline \multirow[b]{3}{*}{ Material/Source } & \multicolumn{6}{|c|}{ Surface Contamination, dis/min.100 $\mathrm{cm}^{2}$} \\
\hline & \multicolumn{2}{|c|}{ Initial } & \multicolumn{2}{|c|}{ After $1 \mathrm{~h}$} & \multicolumn{2}{|c|}{ After $10 \mathrm{~h}$} \\
\hline & Contact & Smear & Contact & Smear & Contact & Smear \\
\hline Stainless Steel/Hanford & 62,000 & 38,000 & 3,800 & Nondetectable & 2,500 & Nondetectable \\
\hline Stainless Steel/Hanford & 88,000 & 25,000 & 8,800 & Nondetectable & 2,500 & Nondetectable \\
\hline Stainless Steel/Hanford & 69,000 & 19,000 & 3,800 & Nondetectable & 2,500 & Nondetectable \\
\hline Stainless Steel/Hanford & 750,000 & 94,000 & 7,500 & Nondetectable & 7,500 & Nondetectable \\
\hline Epoxy/Rocky Flats & 125,000 & 50,000 & 5,600 & Nondetectable & Background & Nondetectable \\
\hline $\begin{array}{l}\text { Stainless Steel/Rocky } \\
\quad \text { Flats }\end{array}$ & 69,000 & 13,000 & 10,000 & Nondetectable & 3,800 & Nonde \\
\hline Epoxy/Rocky Flats & 250,000 & 3,000 & 11,000 & Nondetectable & 700 & Nondetectable \\
\hline $\begin{array}{l}\text { Stainless Steel/Rocky } \\
\text { Flats }\end{array}$ & 75,000 & 13,000 & 2,500 & Nondetectable & 15,000 & Nondetectable \\
\hline
\end{tabular}

shown in Figure 21. The average contamination level of the ten samples dropped from 2,700,000 to $26,000 \mathrm{dis} / \mathrm{min} \cdot 100 \mathrm{~cm}^{2}$ in the first $6 \mathrm{~min}$ of processing in the steel media, which is a $90 \%$ decrease in the contamination level. The samples were also essentially nonsmearable after this brief treatment in the steel media. After the first 6 min the contamination level continued to decrease, but at a substantially lower rate. After $60 \mathrm{~min}$ of processing in the steel media, the fixed contamination level was $11,000 \mathrm{dis} / \mathrm{min} 100 . \mathrm{cm}^{2}$, representing removal of $96 \%$ of the initial contamination. Subsequent processing of the same samples in the fast-cutting ceramic media (Figure 21) reduced the contamination level by an additional $2 \%$, to $4,500 \mathrm{dis} / \mathrm{min} \cdot 100 \mathrm{~cm}^{2}$. Most of this decrease occurred during the first $15 \mathrm{~min}$.

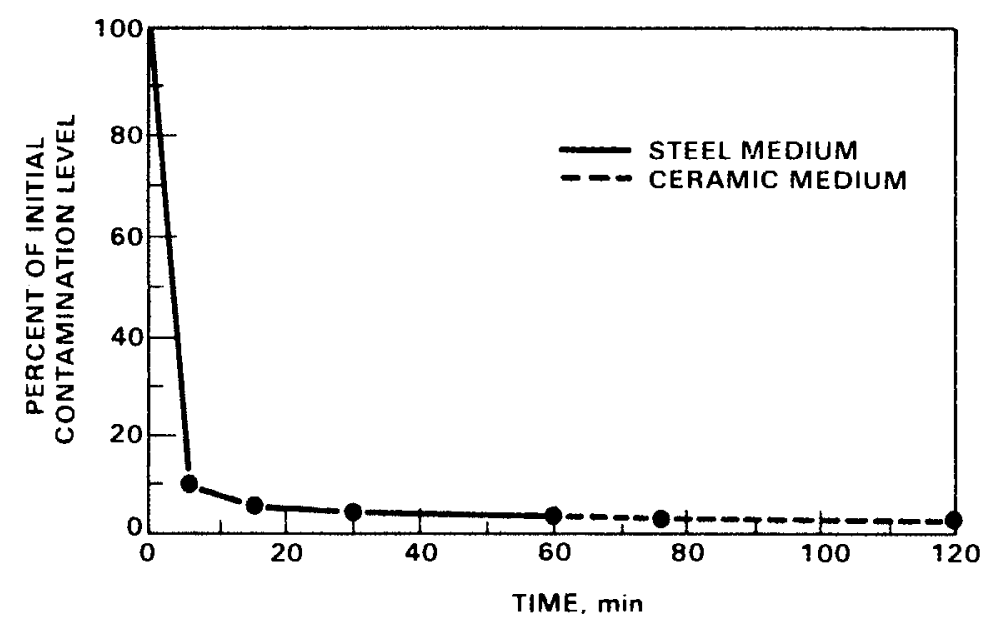

FIGURE 21. Contamination Level Versus Time for Plutonium-Contaminated Glove-Box Pieces Vibratory-Finished for $60 \mathrm{~min}$ in Steel Media Followed by $60 \mathrm{~min}$ in Ceramic Media 
An additional 17 stainless steel, TRU-contaminated glove-box pieces were processed for one hour using the fast-cutting ceramic media and the compound used in the previous test. Eleven of these test pieces, from Rocky Flats' glove boxes, had one side coated with epoxy. Decontamination in the vibratory finisher reduced the average contamination level of the stainless steel surfaces from 250,000 to $3,400 \mathrm{dis} / \mathrm{min} \cdot 100 \mathrm{~cm}^{2}$ and that of the epoxy-coated surfaces from 196,000 to $1,400 \mathrm{dis} / \mathrm{min} \cdot 100 \mathrm{~cm}^{2}$. As before, the vibratory-finished surfaces were essentially nonsmearable.

These tests show that vibratory-finishing techniques, using either ceramic or steel media, are capable of rapidly removing gross plutonium contamination from both metallic and selected nonmetallic (epoxy) surfaces. Although the ceramic media can decontaminate to lower levels, the steel media have the substantial advantage of producing no secondary waste due to media wear. Both types of media also produce essentially nonsmearable surfaces that are ideal for subsequent handling and additional decontamination by electropolishing if desired.

\section{TRANSURANIC DECONTAMINATION DEMONSTRATION}

The effectiveness of vibratory finishing as a decontamination technique for TRUcontaminated waste was further demonstrated by the successful decontamination of more than $400 \mathrm{ft}^{2}$ of plutonium-contaminated metallic waste to below the $10-\mathrm{nCi} / \mathrm{g}$ limit. This demonstration was divided into three parts to permit a direct comparison of processing parameters and effectiveness for: 1) vibratory finishing only, 2) vibratory finishing followed by electropolishing, and 3) electropolishing only. The demonstration was conducted as a productiontype operation, with an emphasis on output and on maintaining realistic processing conditions.

Most of the test material used in the demonstration was typical plutonium-contaminated metallic waste (pipe, ducting, glove-box pieces) generated by the decommissioning of a plutonium facility. The material was sectioned into convenient sizes and shapes using mechanical cutting methods. The sectioning time was not included in the processing time for the decontamination demonstration.

The vibratory-finishing portion of the demonstration was conducted using the 4-ft $\mathrm{fibra-}^{3}$ tory finisher enclosed in the walk-in glove box as in the previous TRU tests. Ceramic media and a commercial, latex-stripper compound were used throughout the demonstration. Relatively hard, ceramic, burnishing media were used initially because of their low wear rate compared to other types of ceramic media. However, it soon became apparent that the media were not providing sufficient cleaning capabilities. Fast-cutting, but higher-wear-rate ceramic media were tried. These media provided excellent cleaning capabilities and were used during most of the demonstration.

The main problems encountered in the vibratory-finishing portion of the demonstration were inadequate rinsing of the material after processing and handling the material in the glove box without recontaminating it. A very effective, two-step rinse was developed consisting of an initial rinse using recirculated compound from the vibratory finisher followed by a rinse with high-pressure, high-purity water. The recontamination problem was solved by using two baskets 
to transport material, one to introduce material into the vibratory finisher and one for the processed material. In addition, clean canvas gloves were worn over glove-box gloves when removing material from the vibratory finisher. These canvas gloves were changed after every run.

The vibratory finisher reduced the contamination level of the test material to an average of $0.11 \mathrm{nCi} / \mathrm{g}$, including $0.005-\mathrm{nCi} / \mathrm{g}$ smearable contamination. After perfecting the rinsing and handling techniques, levels of only $0.0004-\mathrm{nCi} / \mathrm{g}$ smearable were obtained. This level is at the detection limit of Hanford's field alpha-survey instruments. In practice, much of the material had no detectable smearable contamination. Material with excessive smearable contamination was rerun.

of the $315 \mathrm{ft}^{2}$ of material that were vibratory-finished, $131 \mathrm{ft}^{2}$ were subsequently electropolished. The material was randomly selected for electropolishing. The vibratory-finished material was ideal for final decontamination by electropolishing since it could be easily handled and racked because of its low contamination level. In addition, electropolishing time was minimized by the clean, completely conductive surface produced by the vibratory-finishing process. Figure 2, for example, illustrates the ability of vibratory finishing to remove rust and gross contamination even from the inside of pipe sections. The contamination that remained in the vibratory-finished material was concentrated in rough welds or in small gaps at joints.

The last portion of the demonstration was conducted using electropolishing to decontaminate material that had not been processed in the vibratory finisher. The material required repeated electropolishing with scraping and application of paint stripper between runs. This resulted in longer electropolishing times and a much longer handling time per unit of material.

Table 4 summarizes the results of the three-part demonstration. It should be noted that these results represent averages and not optimum values. The time requirements and final contamination levels both decreased as the demonstration progressed, reflecting the normal evolution of research and development type procedures into production-oriented material handling methods. Moreover, these results were generated using sma11, manually operated vibratoryfinishing and electropolishing systems and do not reflect the substantial increase in

TABLE 4. Comparison of Demonstration Results

\begin{tabular}{|c|c|c|c|}
\hline Parameter/Result & $\begin{array}{l}\text { Vibratory } \\
\text { Finishing } \\
\end{array}$ & $\begin{array}{l}\text { Electropolishing } \\
\text { After Vibratory } \\
\text { Finishing } \\
\end{array}$ & $\begin{array}{c}\text { Electropolishing } \\
\text { Without Vibratory } \\
\text { Finishing } \\
\end{array}$ \\
\hline Number of runs & 19.0 & 21.0 & 21.0 \\
\hline Total area processed, $\mathrm{ft}^{2}$ & 315.0 & 131.0 & 118.0 \\
\hline Processing time, min/run & 65.0 & 12.0 & 36.0 \\
\hline Production rate, $\mathrm{ft}^{2} / \mathrm{h}$ & 17.0 & 7.0 & 3.0 \\
\hline Labor, man-h/ft ${ }^{2}$ & 0.14 & 0.37 & 0.72 \\
\hline Final contamination leve $1, \mathrm{nCi} / \mathrm{g}$ & 0.11 & $0.0006^{(a)}$ & $0.0014^{(a)}$ \\
\hline
\end{tabular}

(a) Electropolishing can completely decontaminate metallic surfaces. The objective of this study was just to decontaminate material to well below the $10-n C i / g 1$ imit. 
production rate and decrease in labor requirements that could be realized through system scale up and automation.

The results of the demonstration show that both vibratory-finishing and electropolishing techniques are capable of decontaminating typical TRU-contaminated metallic waste to well below the $10-\mathrm{nCi} / \mathrm{g} 1$ imit and that large amounts of material can be decontaminated on a sustained basis. The results also show that vibratory finishing is a very effective pretreatment method to prepare material for final decontamination by electropolishing.

\section{DECONTAMINATION OF NONMETALLICS}

Although previous studies showed vibratory finishing to be effective for the decontamination of certain nonmetallics (epoxy and rubber), additional tests were conducted to determine the effectiveness of vibratory finishing in decontaminating the wide range of nonmetallics encountered in the decommissioning of TRU facilities. Metal media and a sodium-hydroxide compound were used during these tests. Approximately $40 \mathrm{ft}^{2}$ of Plexiglas taken from a plutonium-contaminated glove-box panel and from a splash guard were processed in the vibratory finisher. The contaminated material was sectioned into 4- by 8 -in. pieces to allow smooth, easy operation. Vibratory finishing reduced contamination to nondetectable levels except in cracks and holes, where levels averaged $0.18 \mathrm{nCi} / \mathrm{g}$. The Plexiglas had a frosted, opaque appearance after processing (Figure 22). A Neoprene gasket was also taken from the glove-box

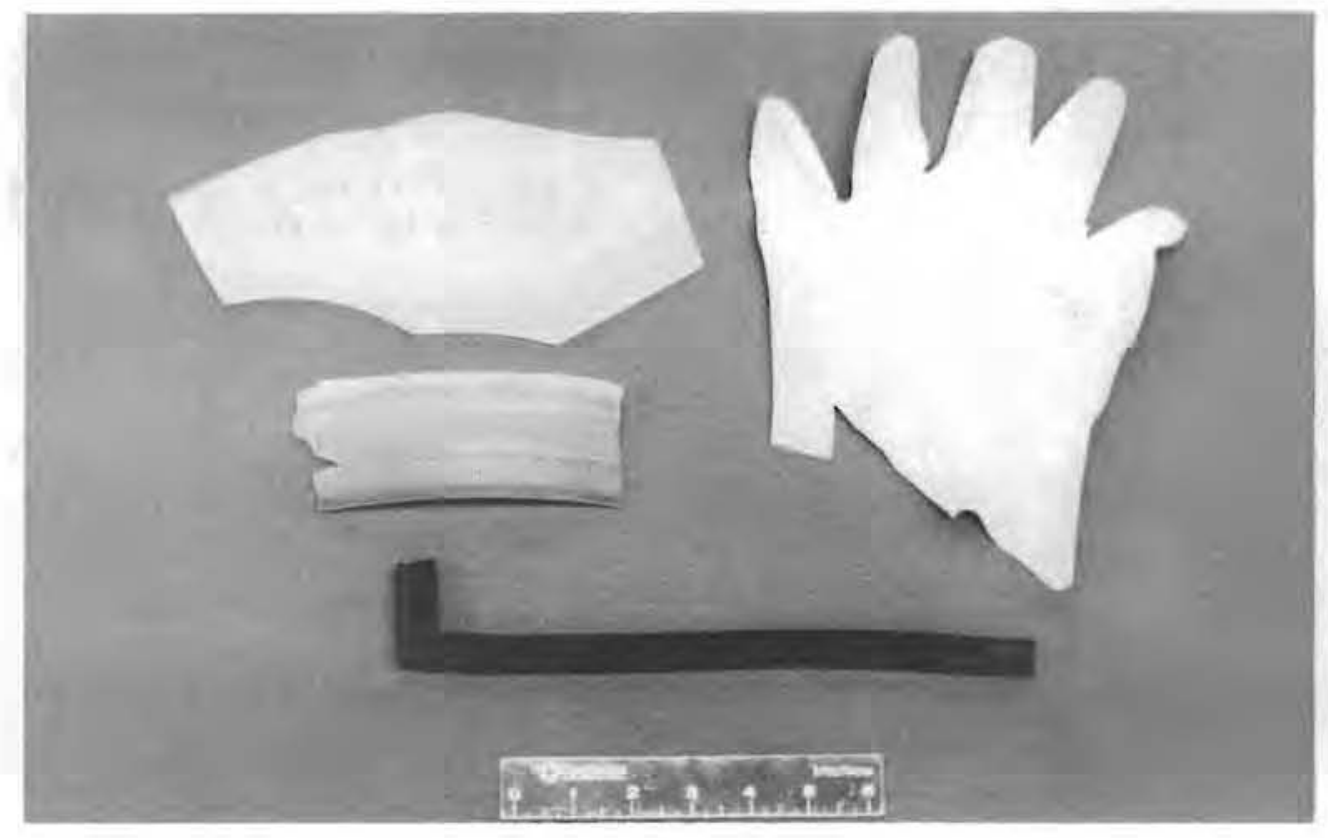

FIGURE 22. Plutonium-Contaminated Nonmetallic Material Decontaminated by Vibratory Finishing (a)

(a) Materials are a Plexiglas section, an Hypalon glove section, a plastic glove port, and a Neoprene gasket. 
pane1, cut into 6 -in. lengths, and processed in the vibratory finisher. The contamination leve1 of the gasket was reduced to nondetectable except in the notch of the gasket, where smearable contamination of about $0.2 \mathrm{nCi} / \mathrm{g}$ was detected.

An entire plutonium-contaminated Hypalon glove-box glove was also processed in the vibratory finisher. The glove was cut along its entire length (Figure 22) to provide all glove surfaces with unobstructed access to the media and compound. The glove rolled with the media but tended to bunch up, shielding some surfaces from decontamination. After one hour of processing, portions of the glove had no detectable contamination while other portions showed little or no decontamination. A contaminated portion, 3 by 6 in., was cut from the glove and was processed for an additional hour. No bunching was observed and contamination was reduced to nondetectable levels. This means that, for successful decontamination, very flexible material such as gloves, bag-out bags or thin plastic sheets must be sectioned to eliminate the bunching.

Plutonium-contaminated glass from a processing tank removed from a facility undergoing decormissioning at Hanford was also successfully decontaminated in the vibratory finisher. The pieces ranged from 4 by 6 in. to 6 by $8 \mathrm{in.} \mathrm{(Figure} \mathrm{23).} \mathrm{The} \mathrm{contamination} \mathrm{levels} \mathrm{of} \mathrm{the} \mathrm{glass}$ were reduced to an average of $0.5 \mathrm{nCi} / \mathrm{g}$.

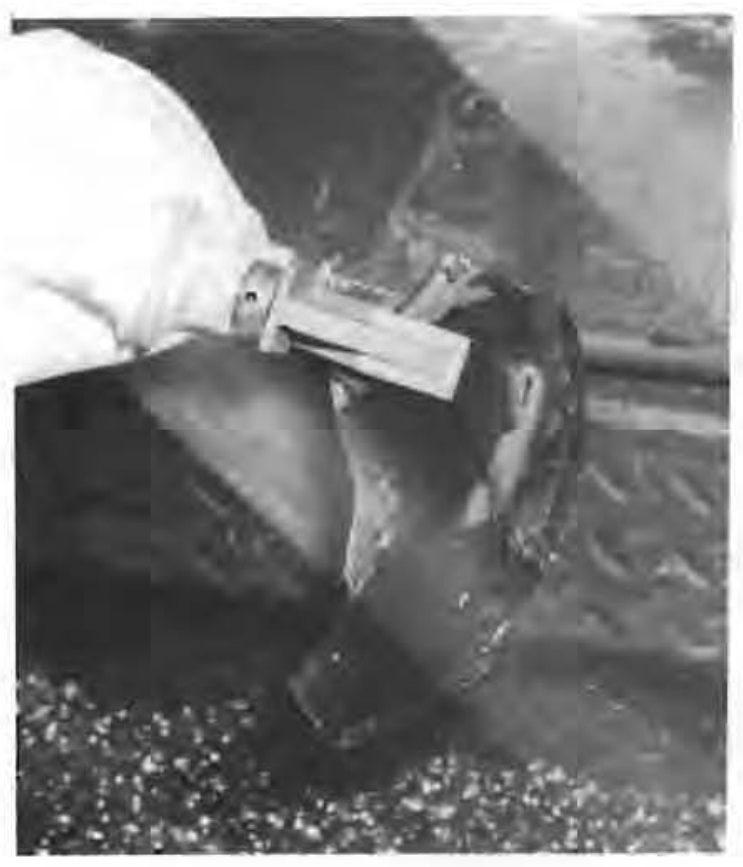

FIGURE 23. Plutonium-Contaminated Glass Decontaminated by Vibratory Finishing

\section{DECONTAMINATION OF A PLUTONIUM-CONTAMINATED GLOVE BOX}

A plutonium glove box with $46 \mathrm{ft}^{2}$ of contaminated surface area (Figure 24) was disassembled, sectioned and converted into non-TRU waste using a combination of vibratory finishing and electropolishing. The decontaminated materials (Figure 25) included the stainless steel 


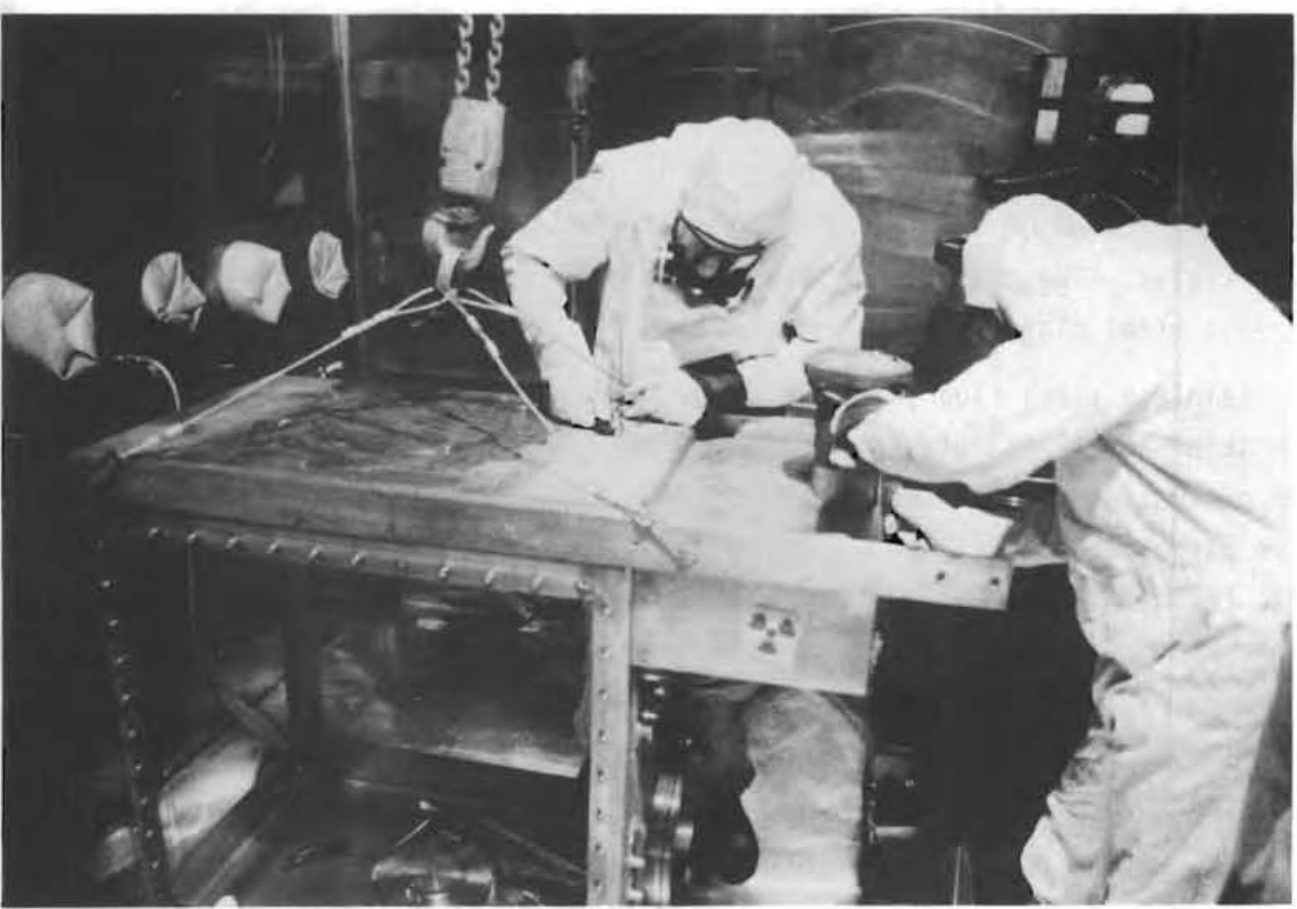

FIGURE 24. Plutonium-Contaminated Glove Box Being Disassembled Prior to Decontamination by Vibratory Finishing
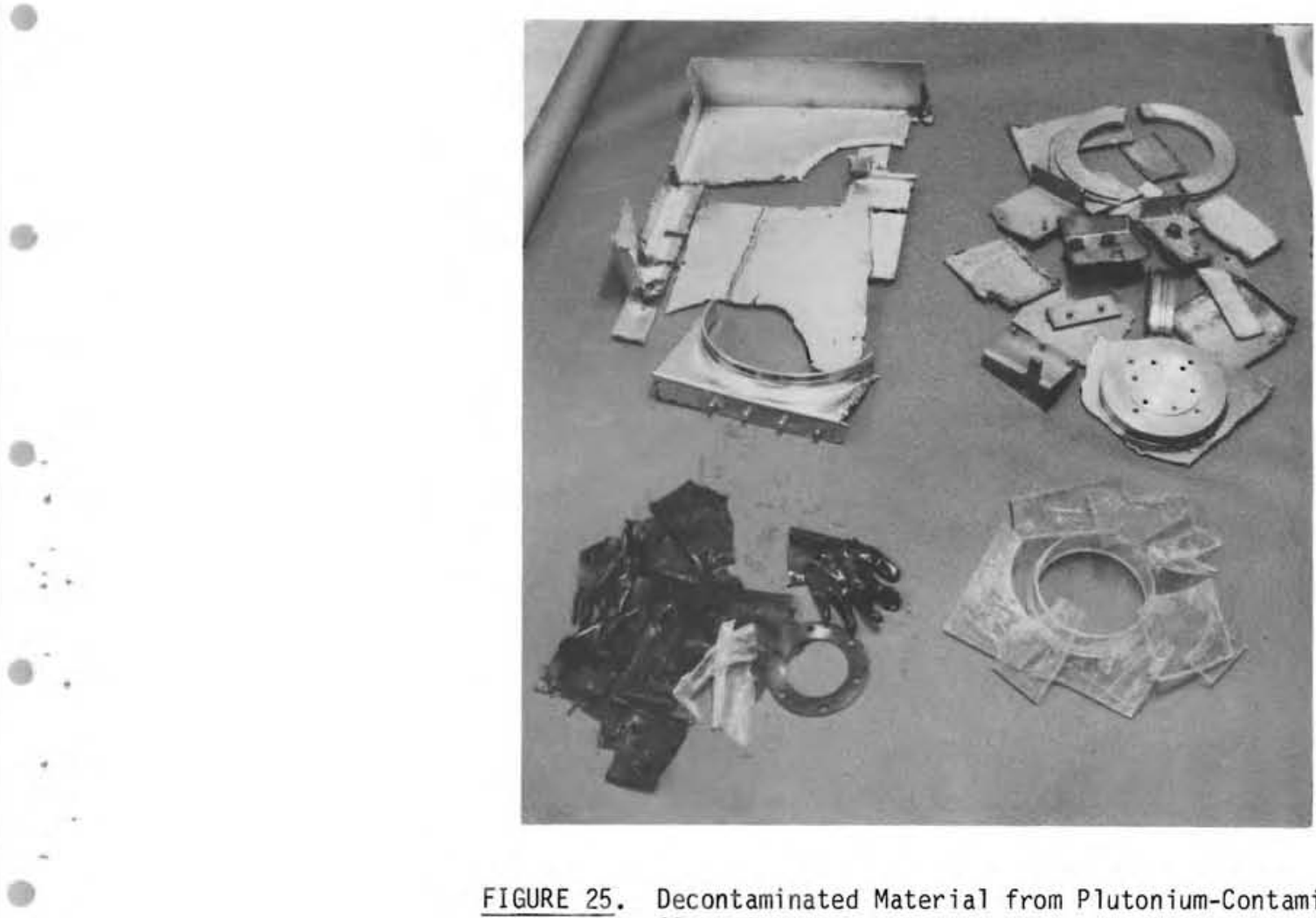

FIGURE 25. Decontaminated Material from Plutonium-Contaminated Glove Box 
glove-box floor, top and frame, the plastic panels, the plastic glove ports, the rubber gloves, and even the plastic bags. The only components that were not processed were the filters and the uncontaminated external hardware.

The glove box was about $24 \mathrm{in.}$ long, $39 \mathrm{in.}$ wide and $26 \mathrm{in.} \mathrm{high.} \mathrm{The} \mathrm{floor,} \mathrm{top} \mathrm{and}$ frame were constructed of 3/15-in. stainless steel. The side panels were constructed of 1/4-in. Plexiglas. The contents of the box included a ram and die set, several dies, and miscellaneous steel plates.

The stainless steel floor, top and frame were sectioned using a hand-held plasma-arc torch. Most of the $32 \mathrm{ft}^{2}$ of stainless steel were sectioned into squares of approximately 8 in. for processing in the vibratory finisher. The remaining stainless steel was sectioned into three pieces about $6 \mathrm{ft}^{2}$ each for treatment by direct-immersion electropolishing. The Plexiglas, representing about $14 \mathrm{ft}^{2}$ of the total contaminated surface area, was sectioned by scoring it and breaking it into approximately 8 -in. squares for decontamination by vibratory finishing.

The stainless steel, Plexiglas, gaskets, gloves and miscellaneous sections were decontaminated simultaneously in the vibratory finisher. Steel media and a sodium-hydroxide compound were used. There was no need to segregate the material by type or size. The vibratoryfinished material was then rinsed using a high-pressure water spray. Processing times were typically one hour. All material was less than $1 \mathrm{nCi} / \mathrm{g}$ after decontamination with some material less than $0.1 \mathrm{nCi} / \mathrm{g}$.

This test showed that using steel media with sodium hydroxide as the compound effectively reduces TRU contamination levels of the major metallic and nonmetallic materials from a typical glove box. Wear rates for the processed stainless steel were from 0.01 to $0.02 \mathrm{wt} \% / \mathrm{h}$. 


\section{ADDITIONAL VIBRATORY-FINISHING TESTS AND CONSIDERATIONS}

The research described in the previous section showed that vibratory finishing is an effective technique for removing plutonium and other radionuclide contamination from a variety of metallic and nonmetallic surfaces. Most of the decontamination occurred within the first 20 min of vibratory finishing. Metal media were shown to decontaminate waste to less than $10 \mathrm{nCi} / \mathrm{g}$, the limit for TRU waste, while producing virtually no solid secondary waste. Ceramic media were also effective, but their use is limited due to the volume of secondary waste they produce. In this section some additional vibratory-finishing tests and considerations are discussed, such as the decontamination of softer materials and the decontamination of metal media.

\section{LIMITATIONS OF VIBRATORY FINISHING}

The decontamination of softer materials, such as copper and lead, using vibratory finishing with steel media was evaluated. Transuranic-contaminated copper and lead sections were processed along with stainless steel and Plexiglas sections. The levels of fixed contamination on the lead and copper increased during vibratory finishing, although smearable contamination was reduced to nondetectable levels. Further tests will be conducted to determine whether the fixed contamination levels on these softer materials can be successfully reduced by changing the vibratory-finishing operating parameters.

Decontamination by vibratory finishing is also limited to surface contamination. Even though proper media selection allows decontamination of a wide variety of configurations, there may be parts that have surfaces that are inaccessible to any media.

\section{MEDIA DECONTAMINATION}

During the processing of plutonium-contaminated waste in the vibratory finisher, the contamination levels of the metal media (1/4-in. ballcones) began to rapidly increase. This sudden increase in contamination was traced to the processing of plutonium-contaminated aluminum using sodium hydroxide as the compound. The sodium hydroxide reacted chemically with the aluminum causing a film of contamination to form on the ballcones. An inspection of the ballcones disclosed a minute area on the ballcone that is inaccessible by other ballcones, preventing the removal of the contaminated $\mathrm{film}$ by the normal self-cleaning process. The problem was rectified by the addition of a commercial acidic compound that chemically removed the contaminated film. Once the contamination level of the media stabilized, sodium hydroxide was once again used as the compound and the contamination level of the media remained stable. This problem may be avoided in the future by the use of cone-shaped meizi media that possess similar cleaning properties to the ballcone, but do not have inaccessible suriaces and should be completely self-cleaning. In addition, the use of a sodium-hydroxide compound should be avoided when decontaminating aluminum in the vibratory finisher. 


\section{DECONTAMINATION OF MOLYBDENUM}

An annular, high-production vibratory finisher with a $12-\mathrm{ft}^{3}$ capacity and an integral media-separation screen was used with chemical decontamination techniques to decontaminate $3000 \mathrm{lb}$ of uranium-contaminated molybdenum (Figure 26). Fast-cutting ceramic media and a commercial deburring compound were used during this test. Up to $600 \mathrm{lb}$ of molybdenum were processed per batch. The typical processing time was one hour/batch. The final contamination levels were reduced to less than $2200 \mathrm{dis} / \mathrm{min} \cdot 100 \mathrm{~cm}^{2}$, which allowed unrestricted release of the molybdenum.

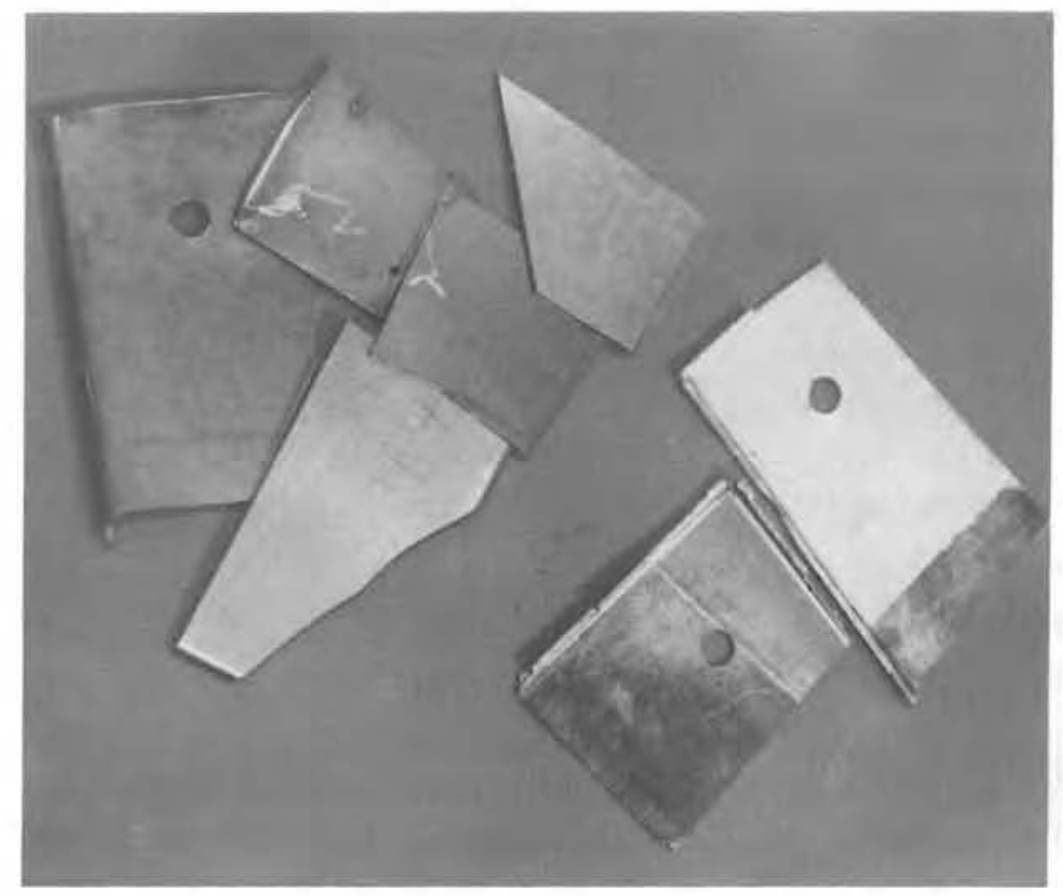

FIGURE 26. Uranium-Contaminated Molybdenum Decontaminated by Vibratory Finishing 


\section{SOLUTION HANDLING}

Efficient handling of the liquid waste generated by the vibratory-finishing process is the key to the effective use of this process as a decontamination technique. In traditional metal-finishing applications, the waste from vibratory finishing is simply discharged down a convenient drain. While water-quality regulations are beginning to change this practice, the regulations faced by the metal-finishing industry are not nearly as stringent as those faced by the nuclear industry for the disposal of radioactive waste. Several techniques were evaluated for handling radioactive waste from vibratory finishing. These techniques minimize the volume of waste generated and allow for final disposal in approved forms.

\section{RECIRCULATION SYSTEM}

The recirculation system, shown in Figure 27, generates the least volume of secondary waste. In this system, a batch of liquid compound is prepared in a settling tank. The 1iquid compound is then pumped from the top of the settling tank into the vibratory finisher. The secondary waste from the vibratory-finishing process is then collected in the settling tank. The solid particles are allowed to settle to the bottom of the tank, which is lined for easy removal of the resulting sludge. Approximately $90 \%$ of the $5-\mu m$ and larger particles settle out in this settling tank. The liquid is then filtered and recirculated through the vibratory finisher as before. Concentrated compound is added periodically to replace the chemicals that are consumed during the vibratory-finishing process. The liquid compound is changed when sludge builds up (if ceramic media are used), when radiation levels in the collection tank increase, or when fissile material concentrations approach criticality safety limits.

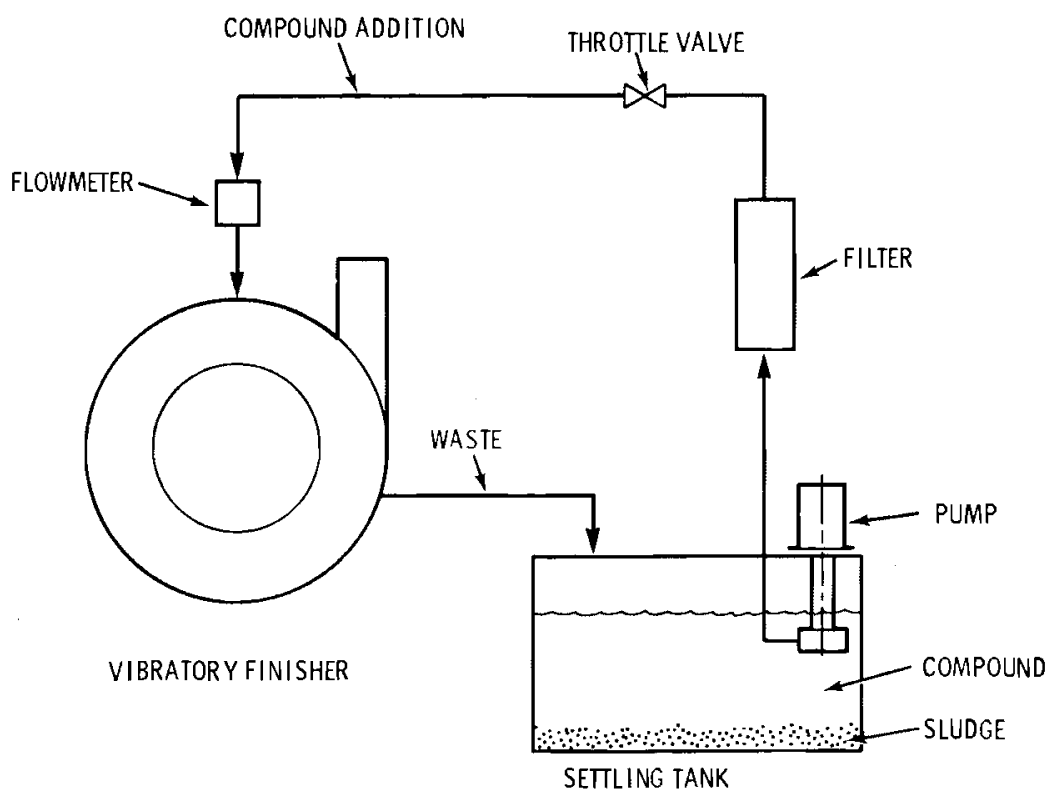

FIGURE 27. Recirculation System for Liquid Compound Used in Vibratory-Finishing Decontamination 
The amount and type of solid waste that is collected in the settling tank will depend on whether ceramic or metal media are used. When metal media are used, most of the solid waste will be collected by the filters; a two-stage filtration system with a 15-um filter followed by a 1- $\mu \mathrm{m}$ filter is very effective. Only trace amounts of solid waste will be collected in the settling tank. However, the use of ceramic media creates problems due to the large amount of waste generated by media self-wear. This can range up to $1.2 \mathrm{wt} / \mathrm{h}$, corresponding to the generation of about $2.4 \mathrm{lb} / \mathrm{h}$ of waste from a small $4-\mathrm{ft}^{3}$ vibratory finisher. Even though about $90 \%$ of the suspended solids can be removed by the settling tank, the remaining particles, ranging to less than $0.25 \mu \mathrm{m}$, rapidly plug the filters requiring frequent filter changes.

An additional disadvantage of the recirculation system is that the compound rapidly becomes dirty, which reduces its effectiveness in removing the waste from the vibratory tub. Therefore, parts decontaminated using a recirculation system require very thorough $r$ insing to remove this contaminated compound residue.

\section{FLOW-THROUGH SYSTEM}

Flow-through systems are normally used in the metal-finishing industry where waste disposal is not a critical problem. The system shown in Figure 28 consists of a water supply to

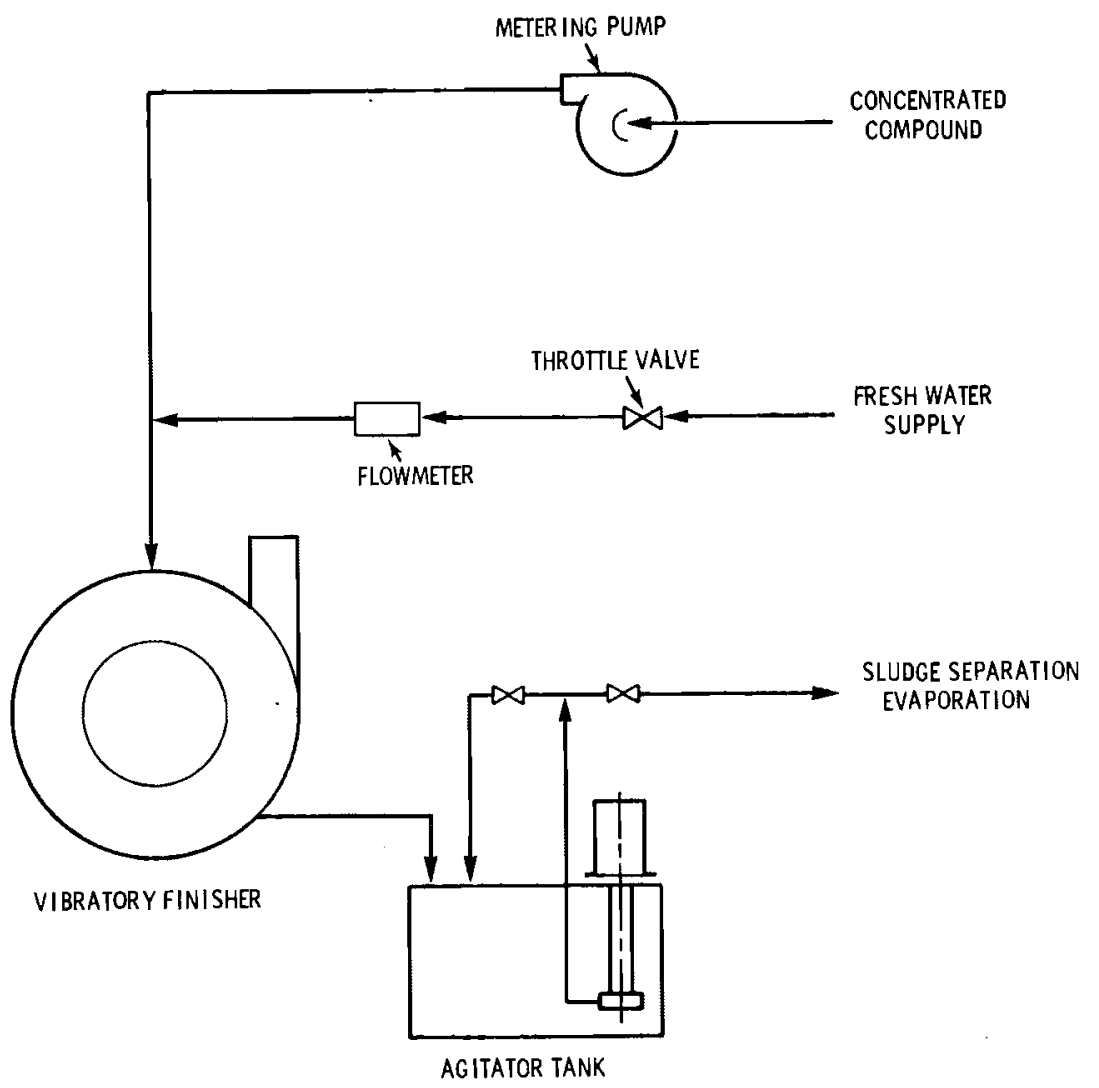

FIGURE 28. Flow-Through System for Liquid Compound Used in Vibratory-Fin ishing Decontamination 
which concentrated compound is added. This solution is then passed through the vibratory tub and the resulting waste is collected in a holding tank. An agitation tank has been used successfully to collect the resulting waste and keep the solid particles in suspension until the liquid can be pumped to a waste-processing system for clarification and final disposal. The operation of this system is the same whether ceramic or metal media are used.

The chief advantage of the flow-through system is that clean compound is constantly used which results in more efficient removal of waste from the vibratory tub. The proper use of this system can reduce or even eliminate entirely the need for rinsing after vibratory finishing. The disadvantage of this system is the volume of waste generated, about 2 gal of liquid per hour of operation for each cubic foot of machine capacity, plus any solid waste generated.

\section{EVAPORATION OF THE LIQUID}

The volume of clarified liquid from either the recirculation or flow-through system can be reduced by evaporation. A dual-phase vacuum evaporator (Figure 29) installed in the 231-Z Building was used to successfully process clarified liquid generated by vibratoryfinishing decontamination. This evaporator has the capacity to purify up to $60 \mathrm{gal}$ of liquid per hour. The distillate is discharged into a nonradioactive drain after proper certification is obtained. The concentrated bottoms from the evaporator are solidified with cement before being disposed of as solid, low-level radioactive waste.

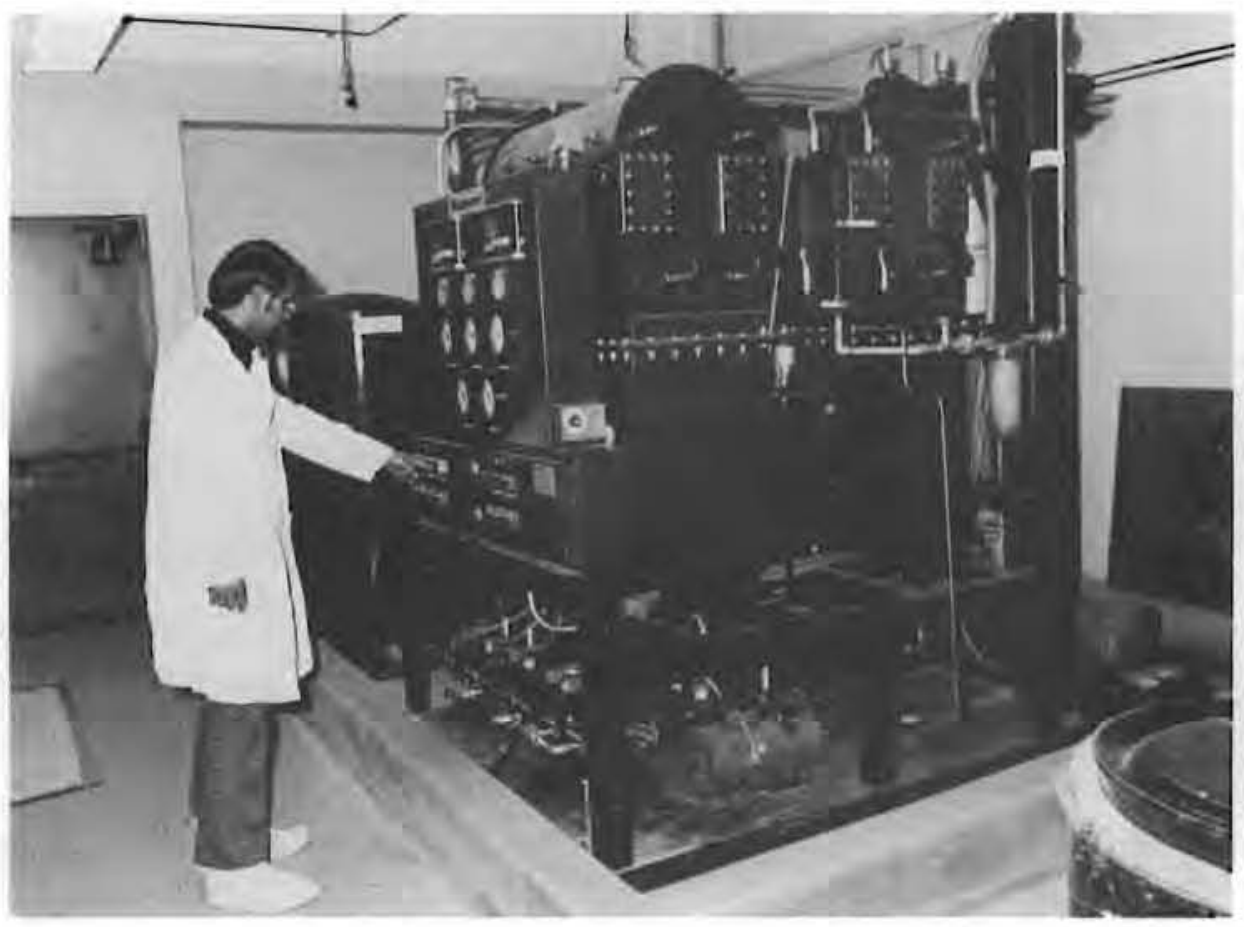

FIGURE 29. Dua1-Phase Vacuum Evaporator Used to Heat Liquid Waste from Vibratory-Finishing Decontamination 
During the evaporation of vibratory-finishing waste, foaming caused by some of the commercially prepared compounds can be a problem. Foaming can result in carry-over of radionuclides into the distillate. The problem can be remedied by the use of low-foaming compounds or by the addition of commercially available defoaming agents. Pretesting of compounds to identify suitable defoaming agents is advised.

\section{WASTE CLARIFICATION}

Liquid waste must be clarified before it is evaporated to avoid sludge formation in the bottom of the evaporator. Several clarification techniques were evaluated including centrifuging, filtration, and chemically enchanced settling. Of these techniques, filtration and the use of polyelectrolytes to promote settling appear to be the most promising.

Filtration is particularly effective for the waste generated when metal media are used. The small volume of solids produced when using metal media is easily removed by 1 - $\mu$ m filters. However, filtration alone is not effective for waste generated when ceramic media are used due to the large volume of very fine particles present in such waste. As mentioned above, these fine particles quickly plug the filter cartridges and fill the filter housing.

The use of polyelectrolytes enhances the settling of the solid waste prior to filtration. Polyelectrolytes, which are polymers of high molecular weights, have been used successfully as clarifying agents for water and sewage treatment (Gutcho 1977). Laboratory tests showed that polyelectrolytes both increase the volume of solids that settle from the liquid and reduce the time that is required for separation (Figure 30 ). However, these tests also

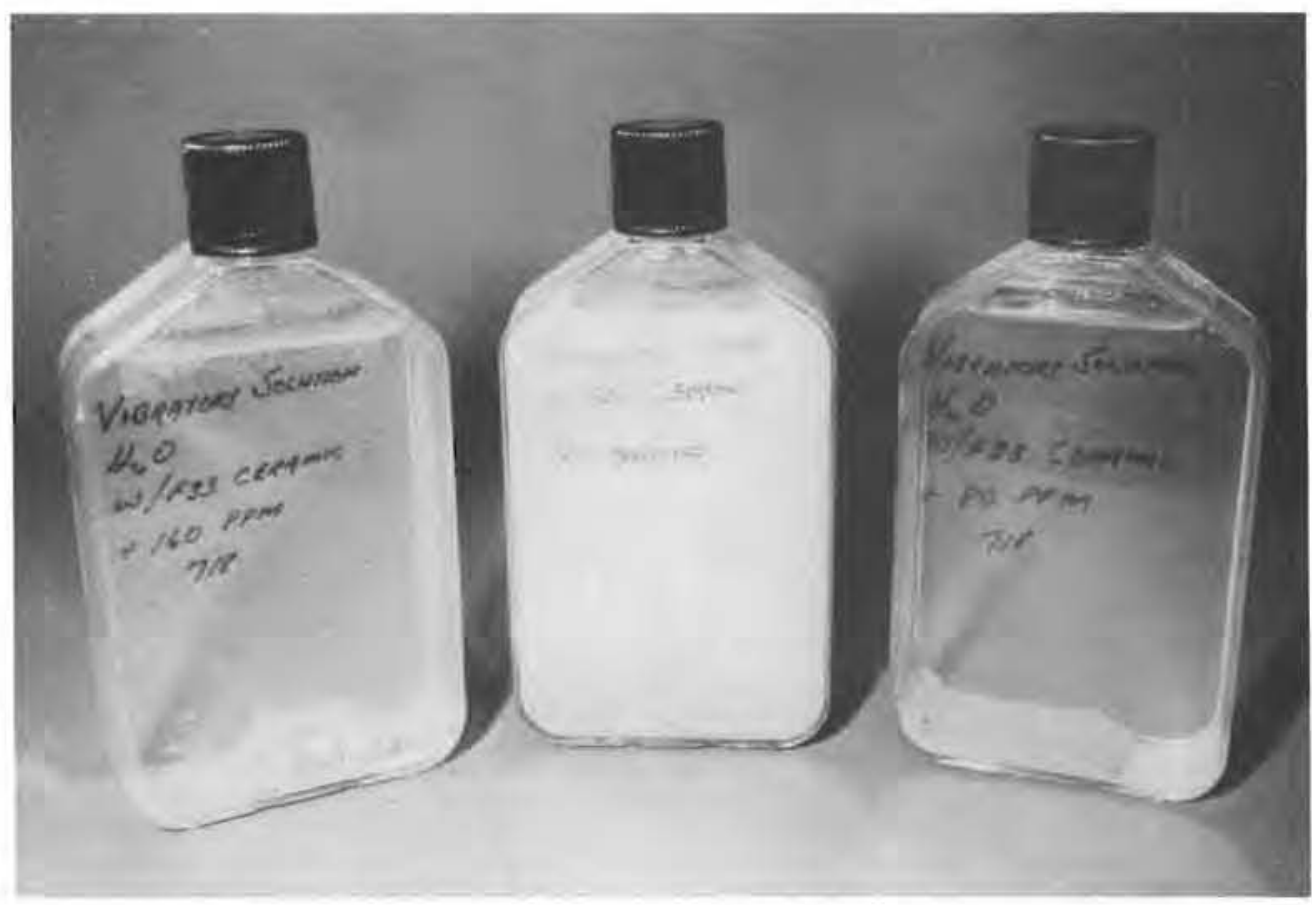

FIGURE 30. Clarification of Vibratory-Finishing Waste Using Polyelectrolytes 
showed that individual polyelectrolytes are effective only for specific waste solutions. A polyelectrolyte for universal application to vibratory-finishing waste has not been identified.

The use of a centrifuge was also tested for the clarification of vibratory-finishing waste. The tests showed that while it was possible to separate the sludge from the liquid, the sludge could not be easily removed from the centrifuge bowl. Additional tests will be conducted to determine changes in operating parameters that will facilitate the removal of the sludge from the centrifuge bowl. 
Criticality safety studies are important whenever there is a possibility of fissionable material becoming concentrated within a system. Therefore, criticality safety analyses were performed for both tub-type and annular-type vibratory-finishing systems. The results of the analyses clearly show that the vibratory-finishing systems will remain subcritical during normal operating conditions.

\section{TUB-TYPE MACHINE}

A detailed criticality analysis was conducted on the 4-ft ${ }^{3}$ tub-type vibratory finisher (Figure 7) used for the initial decontamination tests. At a plutonium density of $1000 \mathrm{~g} \mathrm{plu-}$ tonium/L of interstitial solution, the calculated neutron multiplication factor (Keff) was 0.77 with $1-i n$. water reflection and 0.87 with 5 -in. water reflection.

Criticality analyses of possible sludge tank designs indicated that a 4-in.-thick slab geometry sludge tank with full water reflection will remain subcritical to a plutonium concentration of $40 \mathrm{~g}$ plutonium/L; with nominal water reflection, $K_{\text {eff }}$ will equal 0.95 to a plutonium concentration of $80 \mathrm{~g}$ plutonium/L. The volume of the tank would be $80 \mathrm{~L}$. Thus, the tub-type vibratory finisher can tolerate a higher plutonium solution concentration than can the sludge tank. Previous experience has shown that higher radionuclide concentrations are to be expected in the sludge tank than in the vibratory finisher. Therefore, the sludge tank will be the limiting factor for criticality safety in a vibratory-finishing system with a tub-type vibratory finisher.

\section{ANNULAR-TYPE MACHINE}

Criticality safety was also calculated for a $12-\mathrm{ft}^{3}$ annular vibratory finisher currently being tested at the Hanford 231-Z Building. The rough dimensions of the vibratory tub are slightly less than $5 \mathrm{ft}$ in $O D$ with a 13-in.-wide annular region. The normal depth of the media (which are steel) is about 7 in., although this varies due to the inclined bottom of the vibratory tub. The critical mass of plutonium was calculated for several different situations.

The worst case from a criticality standpoint would be the removal of the steel media while retaining fissile material in the solution. If we assume in this case that the fissile material is present in the most conservative solution form, which would be ${ }^{239} \mathrm{pu}$ water mixtures with no acids or other neutron poisons present, then the families of curves showing the effect of material height, plutonium concentration, and neutron reflectors (water) on the effective neutron multiplication factor would be as shown in Figures 31,32 and 33 . In these curves, the $K_{\text {eff }}$ is given for different plutonium concentrations in the range of 10 to $1000 \mathrm{~g}$ plutonium/L for heights in the annulus varying from 1 to $22 \mathrm{in.} \mathrm{For} \mathrm{the} 22-i n$. height, the entire annulus was considered to be as deep as the lowest portion of the tub bottom. This is a conservative 


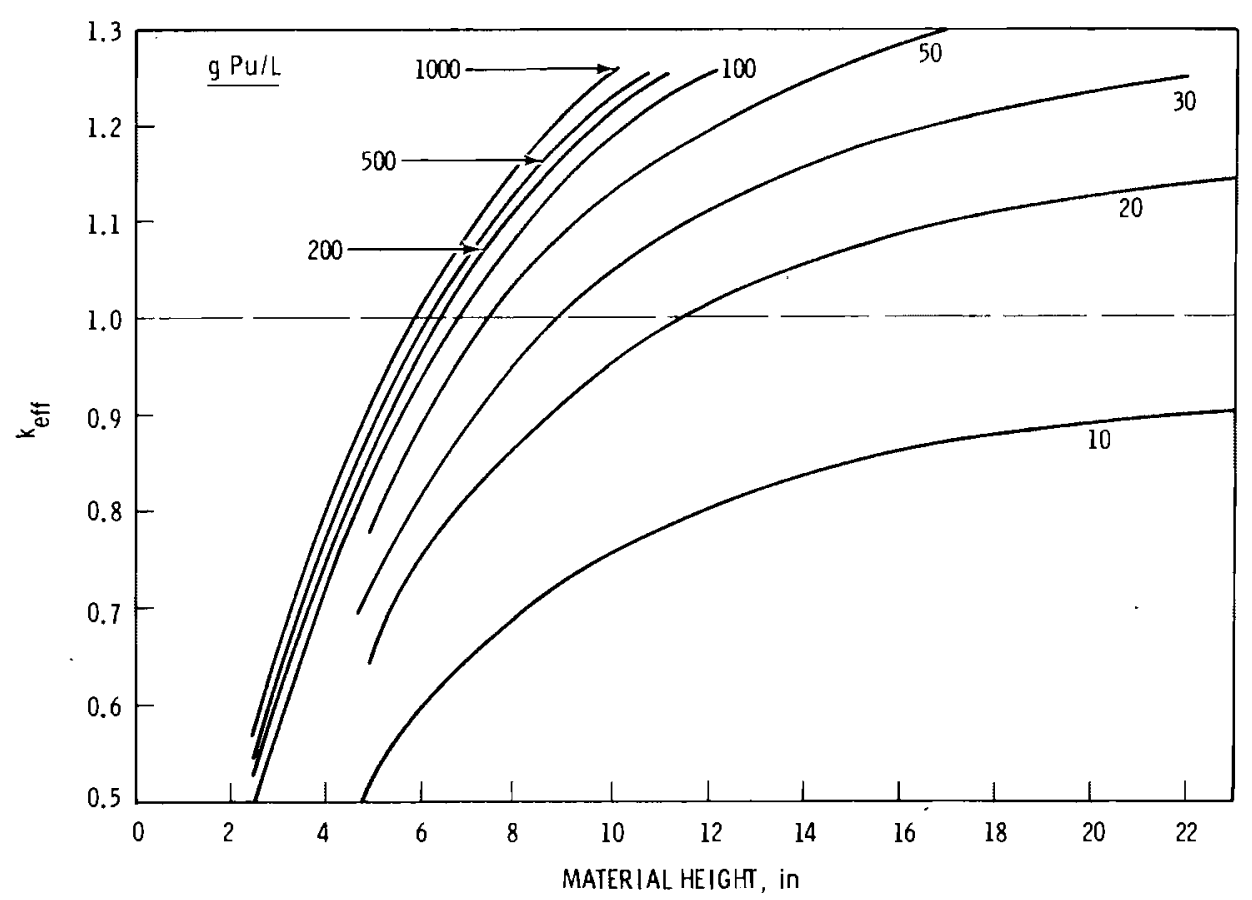

FIGURE 31. Keff Versus Material Height for a 12- $\mathrm{ft}^{3}$ Annular Vibratory Finisher with Bare Reflector Conditions

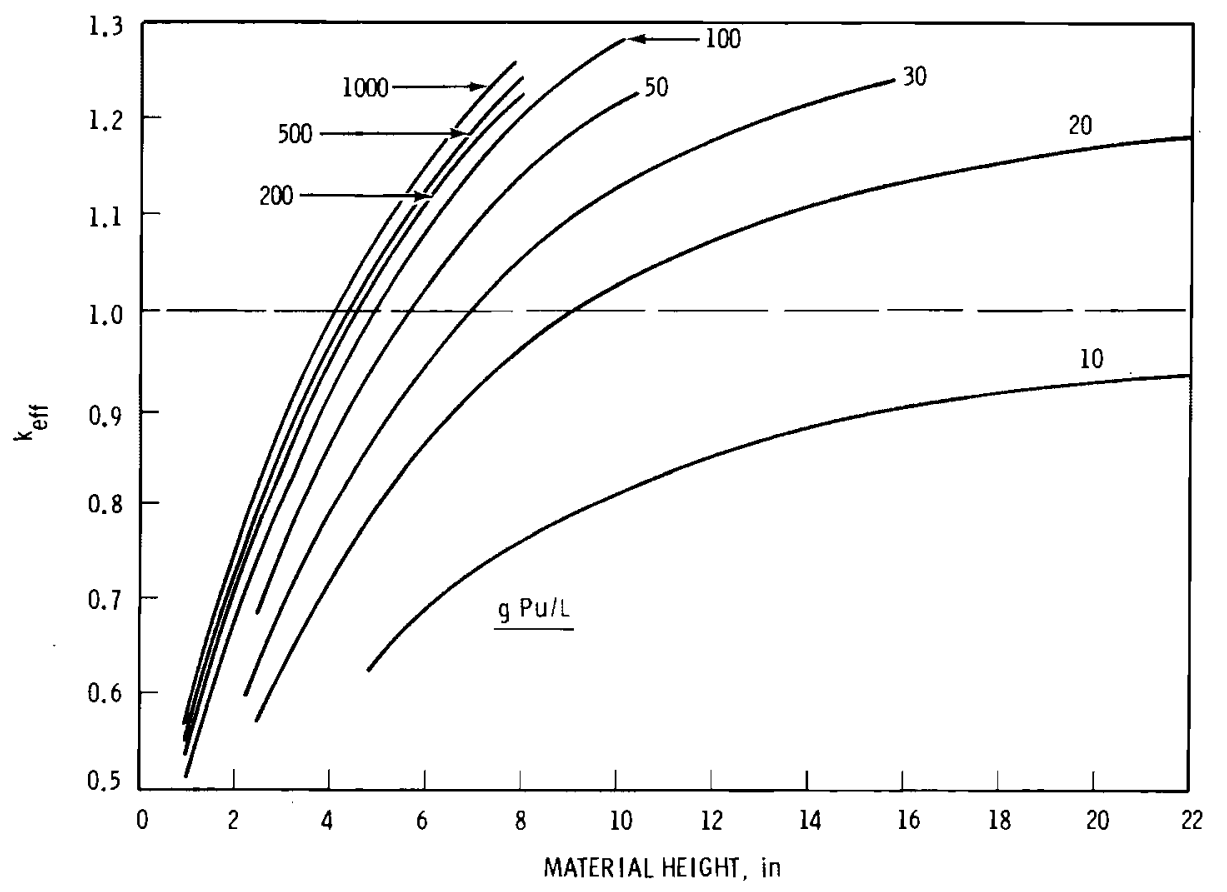

FIGURE 32. Keff Versus Material Height for a 12- $\mathrm{ft}^{3}$ Annular Vibratory Finisher with 1-in. Water Equivalent Reflection 


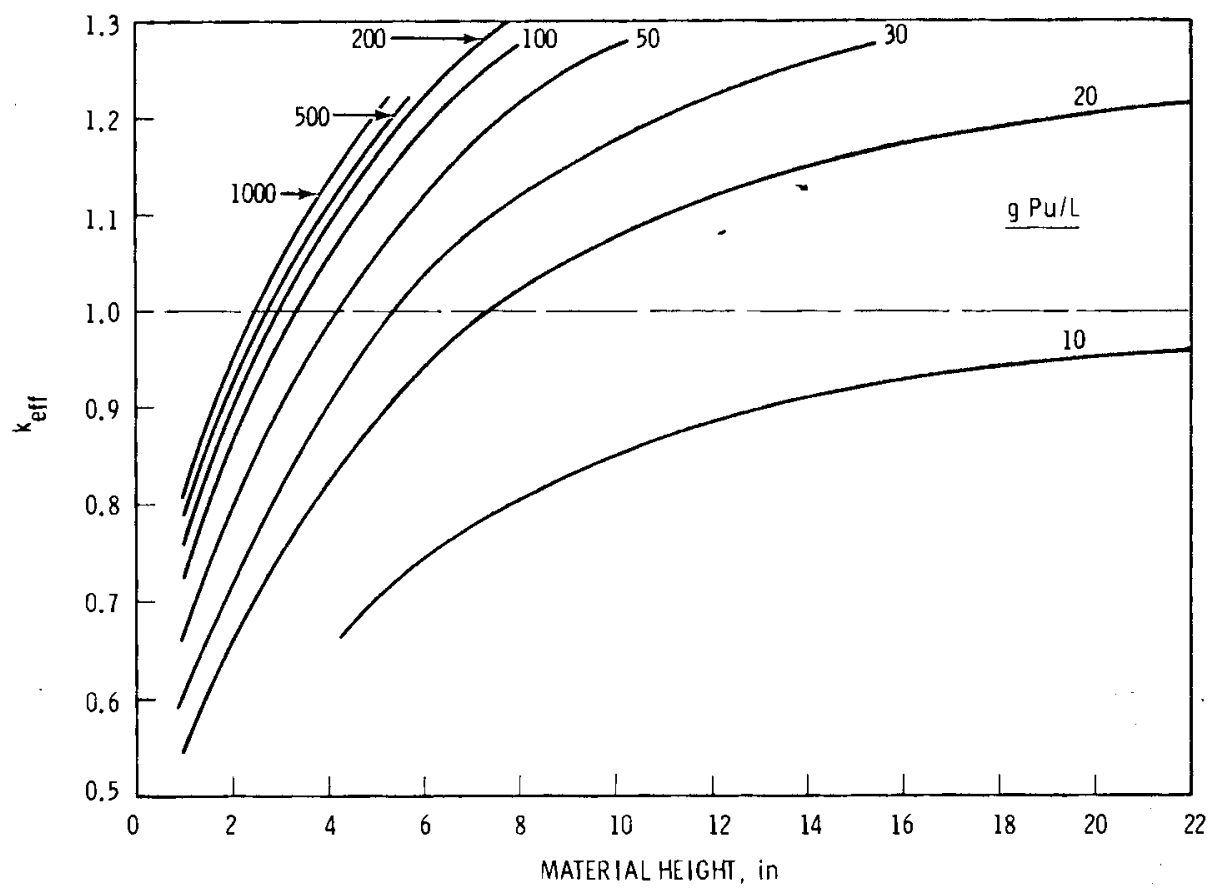

FIGURE 33. Keff Versus Material Height for a 12-ft ${ }^{3}$ Annular Vibratory Finisher with Full Water Equivalent Reflection

assumption. The three reflector conditions were bare, 1 -in. water reflection, and full water reflection. The normal situation is somewhere between bare and 1 in. of water reflection, while full water reflection would approximate a flooded condition for a situation in which personnel would surround the unit (as during repairs).

The data in Figures 31,32 and 33 were further reduced to determine the minimum critical mass in the system. The critical height for a given concentration was determined, and the total volume of solution was calculated. The resulting critical mass values are plotted in Figure 34. These values indicate that the minimum critical mass for the worst combination of reflection, concentration, material form and geometry is about $4.5 \mathrm{~kg}$ of plutonium.

Criticality safety was also calculated taking into account the presence of the steel media. For these calculations, $30 \%$ of the volume was assumed to be a plutonium oxide/water mixture with the remaining $70 \%$ being steel. For these conditions, even with full water reflection and a 22-in. height of material, the unit remained subcritical with plutonium concentrations up to $1000 \mathrm{~g}$ plutonium/L. The total plutonium mass for the $22-i n$. height was $>600 \mathrm{~kg}$ plutonium and for the normal $7-\mathrm{in}$. height was $>200 \mathrm{~kg}$ of plutonium.

In summary, during normal operating conditions the annular vibratory finisher is quite safe in regards to criticality. This is true even with the worst combination of events. 


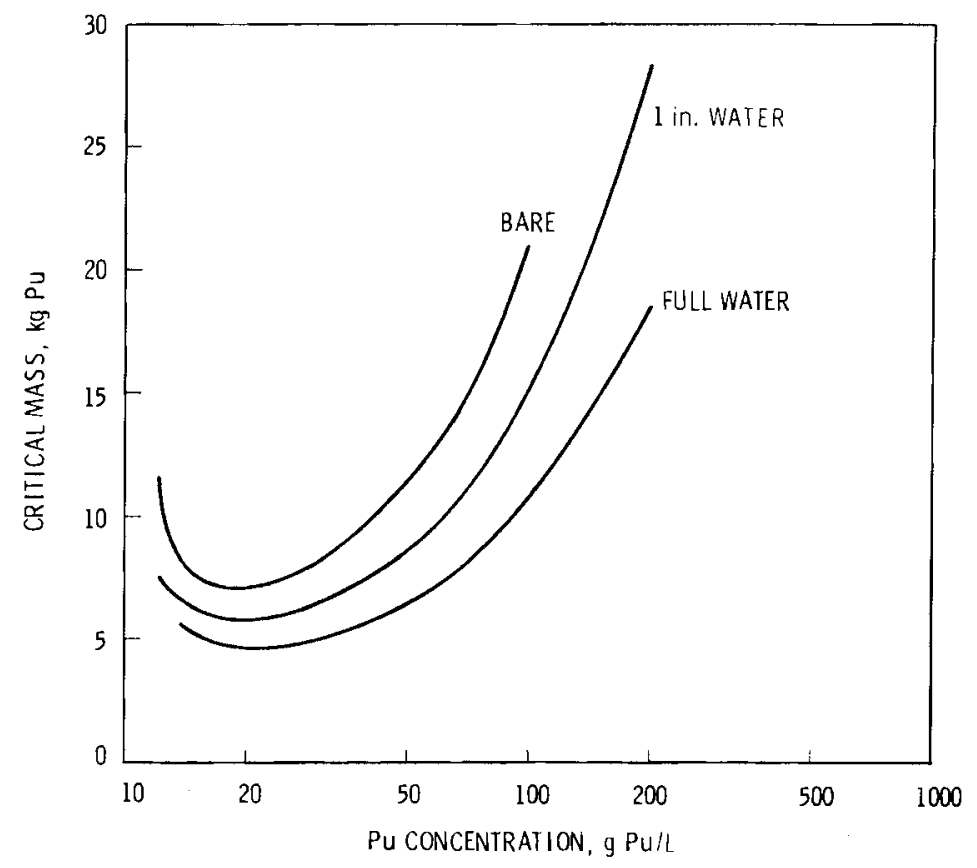

FIGURE 34. Critical Mass Versus Plutonium Concentration for a 12-ft ${ }^{3}$ Annular Finisher for Bare, 1-in. Water Equivalent and Full Water Reflection 
Because vibratory finishing of noncontaminated metals and nonmetals is a well established industrial process, it is possible to transfer much of the needed technology, either directly or with some modification, to the decontamination process. To initiate technology transfer, a consulting agreement was established with Roto-Finish Company, Kalamazoo, Missouri, a leader in the vibratory-finishing field. Discussions with this consultant identified areas in commercial vibratory-finishing technology that are directly useful for decontamination applications, and background information was obtained for those areas that require special development. The topics considered included:

- design of vibratory-finishing systems

- automation concepts

- equipment and suppliers

- media selection

- compound formulation

- rinsing technology

- solution treatment procedures.

Several other companies have also been visited either because they have the capability to vibratory-finish large components, or because they use automated, high-volume vibratoryfinishing systems to surface-finish smaller items. One company, for example, uses vibratory finishers to deburr the blocks of large diesel engines. Another company uses vibratory finishing to deburr wing spars up to $42 \mathrm{ft}$ long. Other industrial firms use large, automated vibratory-finishing systems to process thousands of smaller items (such as ball-point-pen pocket clips) per shift with only one operator to load and unload parts. These and many similar examples show that the use of the automated vibratory-finishing systems to process large volumes of surface-contaminated waste, both metallic and nonmetallic, while minimizing personnel exposure and processing costs is well within the range of existing technology. 
Rapid progress has been made in developing vibratory finishing into an effective decontamination technique for removing TRU and other surface contamination from a variety of materials. The technology is already sufficiently advanced to have many applications as discussed and illustrated in this report. The continued development of vibratory finishing into a largescale decontamination technique should lead to its widespread use in many areas of nuclearwaste management and exposure reduction. The following list is just a sample of some of the possible areas of applications of vibratory finishing as a decontamination technique:

- Use small, portable vibratory-finishing systems for the onsite decontamination of waste from decommissioned facilities to minimize the expense and possible environmental risk of transporting large volumes of highly contaminated waste.

- Convert large volumes of TRU and other surface-contaminated waste into non-TRU waste to substantially reduce the amount of material requiring interim storage and eventual geologic disposal.

- Decontaminate failed equipment and also the tools and equipment used for maintenance operations to substantially reduce radiation exposure to maintenance personnel and at the same time facilitate maintenance operations at operating nuclear industry facilities. 


\section{REFERENCES}

Allen, R. P., et al. 1978. Electropolishing as a Decontamination Process: Progress and Applications. PNL-SA-6858, Pacif ic Northwest Laboratory, Richland, Washington.

Gillespie, L. K. 1976. Deburring-Capabilities and Limitations. Society of Manufacturing Engineers, Dearborn, Michigan.

Gutcho, S. 1977. Waste Treatment with Polyelectrolyte and Other Flocculants. Noyes Data Corp., Park Ridge, New Jersey. 
No. of

Copies

OFFSITE

A. A. Churm

DOE Chicago Patent Group

9800 South Cass Avenue

Argonne, IL 60439

R. Y. Lowrey

DOE Albuquerque Operations Office

P. 0. Box 5400

Albuquerque, NM 87185

A. L. Taboas

DOE Albuquerque Operations Office

P. 0. Box 5400

Albuquerque, NM 87185

S. A. Mann

DOE Chicago Operations and Region Office

Argonne, IL 60439

J. Neff

Department of Energy

Columbus Program Office

505 King Avenue

Columbus, $\mathrm{OH} 43201$

W. E. Mott

DOE Division of Environmental Control Technology

Washington, DC 20545

J. P. Hamric

DOE Idaho Operations Office

550 2nd St.

Idaho Falls, ID 38401

J. W. Peel

DOE Idaho Operations office

550 2nd St.

Idaho Falls, ID 38401

J. B. Whitsett

DOE Idaho Operations Office

550 2nd St.

Idaho Falls, ID 38401

C. R. Cooley

DOE Nuclear Waste Management Programs

NEW, B-107, HQ

Washington, DC 20545

G. H. Daly

DOE Nuclear Waste Management Programs

NEW, B-107, HQ

Washington, DC 20545
No. of

Copies

J. E. Dieckhoner

DOE Nuclear Waste Management Programs

NEW, B-107, HQ

Washington, DC 20545

C. H. George

DOE Nuclear Waste Management Programs

NEW, B-107, HQ

Washington, DC 20545

C. A. Heath

DOE Nuclear Waste Management Programs NEW, B-107, HQ

Washington, DC 20545

M. L. Lawrence

DOE Nuclear Waste Management Programs NEW, B-107, HQ

Washington, DC 20545

D. J. McGoff

DOE Nuclear Waste Management Programs

NEW, B-107, HQ

Washington, DC 20545

S. Meyers/R. Romatowski

DOE Nuclear Waste Management Programs NEW, B-107, HQ

Washington, DC 20545

G. Oerte1

DOE Nuclear Waste Management Programs NEW, B-107, HQ

Washington, DC 20545

A. F. Perge

DOE Nuclear Waste Management Programs

NEW, B-107, HQ

Washington, DC 20545

R. W. Ramsey, Jr.

DOE Nuclear Waste Management Programs

NEW, B-107, HQ

Washington, DC 20545

D. L. Vieth

DOE Nuclear Waste Management Programs NEW, B-107, HQ

Washington, DC 20545

R. D. Walton DOE Nuclear Waste Management Programs NEW, B-107, HQ

Washington, DC 20545

S. W. Ahrends

DOE Oak Ridge Operations Office

P. O. Box E

Oak Ridge, TN 37830 
No. of

Copies

D. Large

DOE Oak Ridge Operations Office

P. 0. Box E

Oak Ridge, TN 37830

S. G. Harbinson

DOE San Francisco Operations Office 1333 Broadway

Oak land, CA 94612

E. S. Goldberg

DOE Savannah River Operations Office P. 0. Box A

Aiken, SC 29801

T. B. Hindman

DOE Savannah River Operations Office

P. 0. Box A

Aiken, SC 29801

R. P. Whitfield

DOE Savannah River Operations Office P. 0. Box A

Aiken, SC 29801

Los Alamos Scientific Laboratory

P. 0. Box 1663

Los Alamos NM 87544

J. B. Martin

Division of Waste Management

Nuclear Regulatory Commission

Washington, DC 20555

D. M. Rohrer

Division of Waste Management Nuclear Regulatory Commission

Washington, DC 20555

R. Dale Smith

Division of Waste Management

Nuclear Regulatory Commission

Washington, DC 20555

R. E. Cunningham

Office of Nuclear Safety Materials and Safeguards

Nuclear Regulatory Commission

Room 562

7915 Eastern Avenue

Silver Springs, MD 20910

324 DOE Technical Information Center

J. A. Buckham

Allied-General Nuclear Services

P. 0. Box 847

Barnwe 11, SC 29812
No. of

Copies

A. Williams

Allied-General Nuclear Services

P. 0. Box 847

Barnwell, SC 29812

J. W. Bartlett

The Analytical Sciences Corp.

6 Jacob Way

Reading, MA 01867

J. L. Jardine

Argonne National Laboratory

9700 South Cass Avenue

Argonne, IL 60439

J. H. Kittel

Argonne National Laboratory

9700 South Cass Avenue

Argonne, IL 60439

M. J. Steindler/L. E. Trevorrow Argonne National Laboratory

9700 South Cass Avenue

Argonne, IL 60439

H. Recht

Dept. 737-710

Atomics International Division

Rockwell International

Box 309

Canoga Park CA 91304

A. Brandstetter

Battelle Memorial Institute

Office of Nuclear Waste Isolation

$505 \mathrm{King}$ Avenue

Columbus, $\mathrm{OH} 43201$

W. Carbiener

Battelle Memorial Institute

Office of Nuclear Waste Isolation

$505 \mathrm{King}$ Avenue

Columbus, $\mathrm{OH} 43201$

N. E. Carter

Battelle Memorial Institute

Office of Nuclear Waste Isolation

505 King Avenue

Columbus, $\mathrm{OH} 43201$

P. L. Hofmann

Battelle Memorial Institute

Office of Nuclear Waste Isolation 505 King Avenue

Columbus, $\mathrm{OH} 43201$ 
M. Kehnemuyi

Battelle Memorial Institute

Office of Nuclear Waste I solation 505 King Avenue

Columbus, $\mathrm{OH} 43201$

Bever ly Rawles

Battelie Memorial Institute

Office of Nuclear Waste I solation

505 King Avenue

Columbus, $\mathrm{OH} 43201$

Brookhaven Nationai Laboratory

Reference Section

Information Division

Upton, NY 11973

J. R. Potter

Chem-Nuclear Systems, Inc.

P. 0. Box 1866

Bellevue, WA 98009

Combustion Division

Combustion Engineering, Inc.

Windsor, CT 06095

H. Leavenworth

U.S. Department of Interior

Bureau of Mines

Albany Metallurgy Research Center

P. 0 . Box 70

Albany, OR 97321

W. Hanson

Dolphin Associates

P. 0. Box 252

Media, WA 98039

W. H. Baker

E. I. Du Pont de Nemours \& Co.

Savannah River Laboratory

Aiken, SC 29801

M. D. Boersma

E. I. Du Pont de Nemours \& Co. Savannah River Laboratory

Aiken, SC 29801

J. R. Cadeiux

E. I. Du Pont de Nemours \& Co.

Savannah River Laboratory

Aiken, SC 29801

J. L. Cranda 11

E. I. Du Pont de Nemours \& Co.

Savannah River Laboratory

Aiken, SC 29801
Copies

R. G. Garvin

E. I. Du Pont de Nemours \& Co.

Savannah River Laboratory

Aiken, SC 29801

A. S. Jennings

E. I. Du Pont de Nemours \& Co.

Savannah River Laboratory

Aiken, SC 29801

J. A. Kelley

E. I. Du Pont de Nemours \& Co.

Savannah River Laboratory

Aiken, SC 29801

R. Maher

Waste Management Programs

E. I. Du Pont de Nemours \& Co.

Savannah River Plant

Aiken, SC 29801

M. P. McGahee

E. I. Du Pont de Nemours \& Co. Savannah River Laboratory

Aiken, SC 29801

D. L. McIntosh

E. I. Du Pont de Nemours \& Co. Savannah River Laboratory

Aiken, SC 29801

L. W. Meyer

E. I. Du Pont de Nemours \& Co.

Savannah River Laboratory

Aiken, SC 29801

S. Mirshak

E. I. Du Pont de Nemours \& Co.

Savannah River Laboratory

Aiken, SC 29801

J. K. Okeson

E. I. Du Pont de Nemours \& Co. Savannah River Laboratory

Aiken, SC 29801

P. H. Permar

E. I. Du Pont de Nemours \& Co. Savannah River Laboratory

Aiken, SC 29801

J. A. Porter

E. I. Du Pont de Nemours \& Co. Savannah River Laboratory

Aiken, SC 29801

G. B. Levin

EG \& G I daho

P. 0. Box 1625

Idaho Falls, ID 83415 
No. of

Copies

L. Henning

Electric Power Research Institute

3412 Hillview Avenue

P. 0. Box 10412

Palo Alto, CA 94304

R. Williams

Electric Power Research Institute

$3412 \mathrm{Hillview} \mathrm{Avenue}$

P. 0. Box 10412

Palo Alto, CA 94304

J. L. Larocca, Chairman

Engineering Research and Development Authority

Empire State Plaza

Albany, NY 12223

D. M. Rosenbaum

Office of Radiation Programs

U.S. Environmental Protection Agency

1921 Jefferson Davis Highway

Arlington, VA 22202

W. F. Holcomb

Office of Radiation Programs $(A-460)$

U.S. Environmental Protection Agency Washington, DC 20460

Environmental Protection Agency

Technological Assessment Div. (AW-559)

Office of Radiation Programs

U.S. Environmental Protection Agency

Washington, DC 20460

J. R. Berreth

Exxon Nuclear Idaho

P. 0. Box 2800

Idaho Falls, ID 83401

R. A. Brown

Exxon Nuclear Idaho

P. 0. Box 2800

Idaho Falls, ID 83401

C. A. Hawley

Exxon Nuclear Idaho

P. 0. Box 2800

Idaho Falls, ID 83401

D. A. Knecht

Exxon Nuclear Idaho

P. 0. Box 2800

Idaho Falls, ID 83401

G. L. Ritter

Exxon Nuclear Idaho

P. 0. Box 2800

Idaho Falls, ID 83401
No. of

Copies

A. P. Roeh, Manager

Exxon Nuclear Idaho

P. 0. Box 2800

Idaho Falls, ID 83401

T. R. Thomas

Exxon Nuclear Idaho

P. 0. Box 2800

Idaho Falls, ID 83401

File Copy

Exxon Nuclear Idaho

P. 0. Box 2800

Idaho Falls, ID 83401

G. E. Benedict

General Atomics Company

P. 0. Box 81608

San Diego, CA 92138

R. G. Barnes

General Electric Company

175 Curtner Avenue

(M/C 160)

San Jose, CA 95125

H. H. Elliott

General Electric Company

Vallecitos Nuclear Center

Vallecitos Road

Pleasanton, CA 94566

H. E. Wagner

General Electric Company

Castle Hayne Road

P. 0. Box 780

Wilminton, NC 28401

T. Martin

General Public Utilities

P. 0. Box 480

Middletown, PA 17057

L. H. Brooks

Gulf Energy and Environmental Systems

P. 0. Box 81608

San Diego, CA 92138

J. Capella

Health Physics Systems

2727 N.W. 43rd Street

Gainesville, FL 32605

J. D. Tewhey

Lawrence Livermore Laboratory

Box 808

Livermore, CA 94550 
No. of

Copies

S. Tong

Mare Island Naval Shipyard

Stop T-11

Code 2350

Vallejo, CA 94592

R. Roy

202 Materials Research Laboratory

Pennsylvania State University

University Park, PA 16802

C. J. Kershner

Monsanto Research Corporation

Mound Laboratory

P. 0. Box 32

Miamisburg, $\mathrm{OH} \quad 45342$

W. Palmour, I I

2140 Burlington Engineering Laboratories

North Carolina State University

Raleigh, NC 27607

J. P. Duckworth

Plant Manager

Nuclear Fuels Services, Inc.

P. 0. Box 124

West Valley, NY 14171

J. Kirkpatrick

Nuclear Fuel Services

Carolina Avenue

Rewin, TN 37650

R. E. Blanco

Oak Ridge National Laboratory

P. 0. Box $Y$

Oak Ridge, TN 37830

J. 0. Blomeke

Oak Ridge National Laboratory

P. 0. Box Y

Dak Ridge, TN 37830

D. E. Ferguson

Oak Ridge National Laboratory

P. 0. Box Y

Oak Ridge, TN 37830

A. L. Lotts

Oak Ridge National Laboratory

P. O. Box $X$

Oak Ridge, TN 37830

R. S. Lowrie

Oak Ridge National Laboratory

P. O. Box $Y$

Dak Ridge, TN 37830
No. of

Copies

Oak Ridge National Laboratory

Central Research Library

Document Reference Section

Box $X$

Oak Ridge, TN 37830

J. Remark

Quadrex Corporation

1700 Dell Avenue

Campbe11, CA 94008

W. S. Bennett

Rockwe 11 International

Rocky $\mathrm{Flats} \mathrm{Plant}$

P. 0. Box 464

Golden, C0 80401

Lawrence J. Smith

Rockwe 11 International

Rocky Flats Plant

P. 0. Box 464

Golden, C0 80401

E. Vejvoda

Rockwell International

Rocky Flats Plant

P. 0. Box 464

Golden, CO 80401

A. B. Martin

Rockwe 11 International

8900 DeSoto Avenue

Canoga Park, CA 91304

R. D. Taylor

Roto Finish Co.

3700 Milhan Road

Kalamazo, MI 49003

B. Unzens

Roto Finish Co.

3700 Milhan Road

Kal amazo, MI 49003

D. R. Anderson

Sandia Laboratories

Albuquerque, NM 87185

R. Dosch

Sandia Laboratories

Albuquerque, NM 87185

0 . E. Jones

Sandia Laboratories

Albuquerque, NM 87185

R. G. Kepler

Sandia Laboratories

Albuquerque, NM 87185 
No. of

Copies

W. Weart

Sandia Laboratories

Albuquerque, NM 87185

D. E. Harrison

Westinghouse Electric Corp. P. 0. Box 10864

Pittsburgh, PA 15236

W. Tope

Westinghouse Electric Corporation

Penn Center, B 1dg. 2

Box 355

Pittsburgh, PA 15230

R. A. Beall

U.S. Dept. of Interior

Bureau of Mines

Albany Research Center

1450 W. Queen Avenue

Albany, OR 97321

H. W. Godbee

Union Carbide Corp. (ORNL)

Chemical Technology Div.

P. 0. Box $Y$

Oak Ridge, TN 37830

W. C. McClain

Union Carbide Corp. (ORNL)

Chemical Technology Div.

P. 0. Box $Y$

Oak Ridge, TN 37830

R. G. Post

College of Engineering

University of Arizona

Tucson, AZ 87521

P. Macedo

Vitreous State Laboratory

Catholic University of America

Washington, DC 20064

L. L. Hench

Dept. of Materials Science and Engineering

University of Florida

Gainesville, FL 32611

R. G. Bilkales

170-26 84th Avenue

Jamaica, NY 11432

J. B. Kittredge

3801 Winding Way

Kalamazo, MI 49007
No. of

Copies

F. K. Pittman

3508 Sagecrest Terrace

Ft. Worth, TX 76109

ONSITE

12 DOE Richland Operations Office

E. A. Bracken

P. A. Craig

0. J. Elgert

J. A. Fernandez

R. E. Gerton

R. B. Goranson

J. L. Landon

H. E. Ransom

J. J. Schreiber

M. W. Shupe

J. D. White

M. J. Zamorski

13 Rockwell Hanford Operations

H. Babad

L. C. Brown

R. A. Deju

R. J. Gimera

A. W. Graves

D. R. Gustavson

E. J. Kosiancic

C. M. Manry

S. J. Phillips

I. E. Reep

J. H. Roecker

D. D. Wodrich

File Copy

4 UNC United Nuclear Industries

T. E. Dabrowsk

J. F. Nemek

K. L. Orrok

P. J. Robinson

3 Westinghouse Hanford Company
A. G. Blasewitz
R. E. Lerch
G. L. Richardson

367 Pacific Northwest Laboratory
R. P. Allen
N. E. Ballou
A. Brandstetter
R. L. Brodzinski
L. L. Burger
D. B. Cear lock 
No. of

Copies

Pac if ic Northwest Laboratory (continued)

T. D. Chikalla

M. 0. Cloninger

C. M. Devary

R. L. Dillon

P. G. Doctor

C. E. Elderk in

J. R. Eliason

J. W. Finnigan

J. A. Franz

J. J. Fuquay

G. W. Gee

R. W. Goles

B. Griggs

C. R. Hann

A. J. Haverfield

R. F. Hazelton

0 . F. Hill

J. L. Hooper

E. R. Irish

J. H. Jarrett

R. S. Kemper

M. R. Kreiter

L. T. Lakey

T. M. Lambright

J. M. Latkovich
No. of

Copies

R. C. Liikala

G. B. Long

R. P. Marshall

J. L. McElroy

M. W. McCoy (300)

S. A. McCullough (3)

R. D. Nelson (3)

J. F. Nesbitt

J. M. Nielsen/R. W. Perkins

R. E. Nightingale

D. E. Olesen

C. R. Palmer

L. D. Perrigo

A. M. Platt

J. A. Powell

J. V. Robinson

S. C. Slate

G. L. Tingey

C. M. Unruh

H. H. Van Tuyl

J. W. Voss

E. J. Wheelwright

W. R. Wiley

L. D. Williams

W. K. Winegardner

Technical Information (5)

Publishing Coordination Vi (2) 


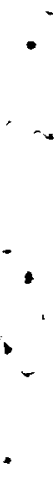

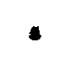

.

- 